\title{
The Rate of Return on Real Estate: Long-Run Micro-Level Evidence*
}

\author{
DAVID CHAMBERS ${ }^{\dagger}$ \\ University of Cambridge
}

\author{
Christophe Spaenjers ${ }^{\ddagger}$ \\ HEC Paris
}

\author{
EVA STEINER ${ }^{\S}$ \\ Cornell University
}

June 2019

\begin{abstract}
We provide evidence that direct real estate investments are less profitable and more risky in the long run than previously thought. We hand-collect property-level data on realized income, expenses, and transaction prices from the archives of four large institutional investors in the U.K.- - historically important Oxbridge colleges - for the period 1901-1970. Gross income yields mostly fluctuate around $5 \%$, but trend to lower (higher) levels for agricultural and residential (commercial) real estate near the end of our sample period. Operating costs mean that net yields are about one third lower than gross yields on average. Long-term real income growth rates are between $-1.0 \%$ and $0.0 \%$ for the three main property types. Together these findings imply limited long-run capital gains and real annualized net total returns of less than $4 \%$ across all property types. Moreover, we find substantial volatility in net income streams and variation in relative price levels across transacted properties, revealing the considerable idiosyncratic risks associated with real estate investments.
\end{abstract}

JEL Classification: G11, G12, G23, N20, R30.

KEYWORDS: real estate, property prices, rental yields, long-run returns, idiosyncratic risks.

${ }^{*}$ We would like to thank David Klingle for excellent research assistance, and Elroy Dimson, William Goetzmann, Rowena Gray, Dmitry Kuvshinov, Thies Lindenthal, Robert Margo, Ludovic Phalippou, Geert Rouwenhorst, Moritz Schularick, Johannes Stroebel, Stijn Van Nieuwerburgh, Joachim Voth, Guillaume Vuillemey, and seminar and conference participants at HEC Paris, London School of Economics, University of Geneva, and the World Economic History Congress 2018 for valuable feedback and data. We are grateful to the Cambridge Endowment for Research in Finance, the Centre for Endowment Asset Management, the Newton Trust, and St John's College, Cambridge for research funding. All errors are ours.

${ }^{\dagger}$ Cambridge Judge Business School. Email: d.chambers@jbs.cam.ac.uk.

${ }^{\ddagger}$ HEC Paris. Email: spaenjers@hec.fr.

${ }^{\S}$ Cornell SC Johnson College of Business. Email: ems457@cornell.edu. 


\section{Introduction}

Real estate has delivered attractive investment returns over the past few decades (e.g., Favilukis et al. (2017), Ghent et al. (2018), Giglio et al. (2018)). ${ }^{1}$ Yet, we possess only a limited understanding of its longer-term track record, especially when compared to our knowledge of historical bond and equity returns (e.g., Jorion and Goetzmann (1999), Dimson et al. (2002)). Recent research by Jordà et al. (2019a) suggests that residential real estate has been a stellar investment in a wide sample of advanced economies since the late nineteenth century. It estimates an average real net return to housing of about $7 \%$ per year, similar to equities. However, measuring the historical performance of direct real estate investments based on existing data sets is an exercise that is severely complicated by different data limitations and methodological challenges, at least up until the 1960s or 1970s. First, available price data typically do not allow for an adequate adjustment for variation in property characteristics. Increases in average prices may thus overstate the capital gains realized by investors if more recently traded properties are of higher average quality. Second, information on the cashflows associated with historical real estate investments is difficult to obtain. When income data exist, they capture contractual (instead of realized) income, and are not drawn from the same set of properties for which transaction prices are observed. Third, detailed data on the costs associated with real estate ownership are typically not available.

In this paper, we overcome these measurement problems, which are presented more formally in Section 2, by exploiting a unique empirical setting where we observe not only transaction prices but also rental income and costs for the same sample of individual properties. More specifically, we construct a data set of the holdings and transactions starting from the early twentieth century for King's College and Trinity College in Cambridge and Christ Church and New College in Oxford. These four prominent colleges were among the wealthiest and most substantial property owners in each university around 1900. Importantly, the data set is not restricted to housing, but also includes agricultural and commercial real estate. The latter two

\footnotetext{
${ }^{1}$ Favilukis et al. (2017) estimate average real returns to U.S. housing of 9-10\%, before maintenance costs and property taxes, over the 1976-2012 period. For U.K. housing, Giglio et al. (2018) document average real net returns of about 7\% over the 1988-2016 period. Ghent et al. (2018) report average nominal returns to privately held commercial real estate of $9-12 \%$ for different periods since the $1970 \mathrm{~s}$.
} 
property types have received less attention in prior literature despite their importance in the real estate portfolios of institutional investors. Furthermore, the micro-level nature of this data allows us to analyze the idiosyncratic risks faced by direct property investors.

Our data cover the period 1901-1970 and are hand-collected from the archives of the four sample colleges. We obtain data on acquisitions and disposals from transaction ledgers and source data on rental income and costs from rent books. We match transactions to the corresponding income records based on property address, tenant name, and other identifying characteristics. In the case of the two Cambridge colleges, archival sources enable us to assemble the full history of rental income across all property holdings for the entire sample period. For the two Oxford colleges, the available records allow us to collect income data for transacted properties for the periods immediately following purchases and preceding sales. Our final data set contains more than 48,000 income observations at the property-year level, and we observe a purchase or sale for nearly 2,000 property-year combinations.

The granular data contained in the college archives allow us to analyze all three major types of real estate; namely, agricultural, residential, and commercial. We first analyze our newly-constructed data set by studying the evolution of real estate portfolios across those three major property types over time. At the start of the twentieth century, both King's and Trinity's portfolios were heavily concentrated in agricultural real estate, which generated more than three-quarters of total gross income. Over the course of the sample period, we document a shift away from agricultural real estate in favor of commercial real estate, which by 1970 is by far the most important property type held by gross income generated. This finding underlines the importance for institutional investors of property types other than housing.

Next, we construct quality-adjusted rental income indices over the 1901-1970 period. Our indices capture the growth in realized income of the property holdings of institutional investors, rather than the growth in average or aggregate contractual rental income in the economy. This distinction is important because market-wide income may increase as new higher-quality properties are added to the existing stock, while the income for any previously-constructed property may not change in the same way. We document that nominal income remains nearly 
constant over the first half of the twentieth century and begins to increase from 1945 at an average rate of $4.6 \%$ per year. Real income growth exhibits substantial cyclicality, mirroring inflation and deflation patterns in the U.K. economy. Crucially, we show that real income has not increased over time; estimated annualized growth rates are $0.0 \%$ for agricultural, $-0.8 \%$ for commercial, and $-1.0 \%$ for residential real estate. These results imply that any positive capital gains for institutional investors in U.K. property over much of the twentieth century must have been driven by income yield compression.

We estimate gross yields associated with real estate transactions by dividing the annual gross income associated with a property by its transaction price. When measured over moving fiveyear intervals and across property types, the mean income yield fluctuates between $4 \%$ and $6 \%$; the long-run average is close to $5 \%$. Average yields are particularly high-implying low relative price levels - in the early 1930s and particularly low - implying high relative prices - just before WWI and near the end of our sample period. We dig deeper into our findings and break down the evolution of yields by property type. Our estimates suggest that the yields of residential, commercial, and agricultural properties are similar until WWII. After 1945, they start to diverge, with yields for agricultural and residential real estate declining, and yields for commercial real estate increasing. Our results highlight that inferences drawn about the performance of real estate as an asset class based on empirical evidence from housing properties alone can be misleading.

When considering the cross-sectional variation in gross yields, we see that there is on average a difference of 3 percentage points between the first and the third quartile in the yield distribution per five-year period, even in times when the different property types have comparable average yields. A regression with a number of transaction-level covariates and fixed effects for property type, college identifier, geographical region, and transaction year leaves $80 \%$ of the variation in gross yields unexplained. Our estimates imply that some properties will generate significantly less (or more) income than expected; others are likely to sell for considerably less (or more) than anticipated. This finding highlights the importance of idiosyncratic risks in real estate investment.

Next, we analyze the holding costs associated with real estate investing. Averaging across years and property types, we estimate a mean cost-to-income ratio of $35 \%$. Commercial real 
estate is associated with somewhat lower average costs, in particular during the final decades of our sample. In aggregate, improvements represent the largest cost category, especially from the mid-twentieth century onwards. At the level of individual properties, we document that the impact of costs increases the volatility in property-level net income streams relative to the volatility of gross income streams. For a given property-year, the probability of a drop in net income of $10 \%$ or more exceeds $20 \%$, which is more than twice as high as for gross income. Our result implies that ignoring the impact of costs may lead to a substantial underestimation of the riskiness of real estate investments.

Our results on net income and yield dynamics imply limited long-run capital gains, and annualized real net total returns of less than $4 \%$ for the different property types. For housing, our estimate is substantially below previous results based on aggregate income and price statistics - often with incomplete quality adjustments - from disparate sources, even for the same geography and time period. The difference mainly lies in the income component of the return to investment. We find an average net income yield of $2.8 \%$ for U.K. residential real estate over the 1901-1970 period, while Jordà et al. (2019a) estimate an average yield of 4.1\% over the same time interval. We show that this discrepancy is related to very different income growth estimates for the two decades following the start of WWII - a period over which the aggregate rent data underlying Jordà et al. (2019a) are thin. In sum, our results indicate that real estate may be a poorer long-term investment than the existing academic literature on housing suggests.

The remainder of this paper is structured as follows. In the next section, we introduce a definition of total returns, review the measurement problems in prior research, and explain how we overcome those methodological issues. Section 3 presents the empirical setting and describes our data collection, the resulting data sets, and summary statistics. Section 4 presents our main findings on portfolio dynamics, income growth, yields, costs, capital gains, and net total returns. The final two sections discuss these results and conclude, respectively. 


\section{Measuring the Returns to Real Estate Investments}

\subsection{Return Definitions}

To understand the nature of direct property investments, we present a decomposition of total returns. We begin by defining the total return to holding property $i$ between time $t-1$ and $t$, net of the costs associated with property ownership, as:

$$
r_{i, t}=\frac{P_{i, t}+\left(1-c_{i, t}\right) Y_{i, t}}{P_{i, t-1}}-1,
$$

where $P_{i, t}$ denotes the market value of property $i$ at time $t$. While $P_{i, t}$ is not continuously observable, it can be proxied by the transaction price $P_{i, t}^{*}$ if a transaction takes place at time $t$. $Y_{i, t}$ is gross rental income and $c_{i, t}$ is the cost-to-income ratio for property $i$ at time $t$, respectively.

We can decompose $r_{i, t}$ from Eq. (1) into its constituent elements, namely net income yield and capital gain, as follows:

$$
\begin{aligned}
r_{i, t} & =\frac{P_{i, t}}{P_{i, t-1}} \times\left[1+\frac{P_{i, t-1}}{P_{i, t}} \times \frac{\left(1-c_{i, t}\right) Y_{i, t}}{P_{i, t-1}}\right]-1 \\
& =\frac{P_{i, t}}{P_{i, t-1}} \times\left[1+\frac{\left(1-c_{i, t}\right) Y_{i, t}}{P_{i, t}}\right]-1 \\
& =(1+\underbrace{k_{i, t}}_{\text {capital gain }}) \times[1+\underbrace{\left(1-c_{i, t}\right) y_{i, t}}_{\text {net income yield }}]-1,
\end{aligned}
$$

where $k_{i, t}$ and $y_{i, t}$ are the capital gain and the gross rental yield of property $i$ as observed in year $t$, respectively. Eq. (2) can be expressed in nominal or in real terms; accounting for inflation affects the computation of the capital gain between $t-1$ and $t$ (i.e., $k_{i, t}$ ), but not the measurement of the income yield at time $t$ (i.e., $y_{i, t}$ ). The total return $r_{\eta, t}$ to property type $\eta$ (i.e., agricultural, commercial, or residential) can then be computed as the value-weighted average total return over all assets $i=1,2, \ldots, N$ in property type $\eta$ at time $t-1$. 


\subsection{Measurement Problems in Prior Literature}

The existing literature on the long-term financial characteristics of real estate investments mainly focuses on housing. Also, most existing work estimates a time series of average capital gains $k_{\eta, t}$, and only less frequently of average total returns $r_{\eta, t}$. Guided by the decomposition of the net total returns to individual property investments shown in Eq. (2), we can summarize the measurement problems faced by prior long-run studies estimating the performance of real estate based on historical data as follows:

Capital gains. Many studies document the historical evolution of aggregate house price indices, based on average transaction values $\overline{P_{\eta, t}^{*}}$ observed in different housing markets. Important contributions include Eichholtz (1997) for Amsterdam, Shiller (2000) for twenty cities in the U.S., and Knoll et al. (2017) for fourteen different countries. However, a time series of changes in

average observed transaction prices $\frac{\overline{P_{\eta, t}^{*}}}{\overline{P_{\eta, t-1}^{*}}}$ overestimates the average capital gains $k_{\eta, t}$ realized by investors if it does not adequately control for changes in the quality composition of the traded real estate stock. In particular, if new properties are, on average, of higher quality than existing ones, then average transaction prices will increase at a rate that exceeds the capital gains of existing investors. This is a well-known problem encountered in empirical studies of housing price trends. For example, the U.K. house price index of Knoll et al. (2017) "does not control for quality changes prior to 1969" (appendix p. 114); more generally, those authors acknowledge that "accurate measurement of quality-adjustments remains a challenge" (p. 342). Next, investors will only realize capital gains in line with a quality-adjusted price index if they properly maintain their property; however, such expenditures are often ignored by the literature, as we discuss in more detail below. Finally, there exists a "superstar city bias" in that many historical studies - even of "national" housing prices - focus on capitals and other large cities (Dimson et al., 2018), which are known to have had a higher-than-average rate of price appreciation historically (Gyourko et al., 2013).

Gross income yields and total returns. Modern financial institutions invest in real estate expressly in pursuit of high rental yields (Hudson-Wilson et al., 2005). However, existing 
empirical studies on the investment performance of real estate largely ignore the rental yield component of total returns. Rental yields are absent from prior research in part because data on the cashflows from real estate investments are difficult to obtain. Unlike transaction prices, rental income observations are not systematically or centrally recorded. Furthermore, existing data capture contractual rental income, which can be significantly higher than realized income due to rent arrears and temporary voids, and thus lead to overstated rental yields. Moreover, where income data are available for property samples, transaction prices are not typically observed for the same properties. As a result, empiricists often combine income and price data from different sources to estimate yields and total returns. For example, Nicholas and Scherbina (2013) add survey data on contractual rents from 54 income-producing local properties to their price index estimated over a different property sample to compute total returns to Manhattan real estate investments between 1920 and 1939. Brounen et al. (2014) combine the long-run Amsterdam price index from Eichholtz (1997) with the rent index from a different set of properties constructed by Eichholtz et al. (2012) to estimate total returns. Most recently, Jordà et al. (2019a) provide total return estimates on housing for fourteen countries by combining price indices from Knoll et al. (2017) and rental income indices estimated from aggregate national statistics in Knoll (2017). However, all such methods introduce a measurement error in the resulting time series of income yield estimates if the underlying price and rent observations are obtained from properties with different (quality) characteristics (Eichholtz et al., 2018). Moreover, using mismatched historical income and price change estimates to extrapolate backward from a contemporary rent-to-price ratio over long periods of time, as in Brounen et al. (2014) and Jordà et al. (2019a), carries the risk of compounding measurement errors over time (Dimson et al., 2018).

Costs. Prior studies on the investment income earned from real estate holdings typically ignore the influence of costs associated with owning and operating real property. For instance, Eichholtz et al. (2012) document the evolution of marked-to-market rents - not net income - in Amsterdam. Where existing studies do account for costs, they rely on small samples of aggregate ratios. Jordà et al. (2019a) attempt to account for the historical costs of property ownership by anchoring their 
estimation to a contemporary aggregate net income yield estimate. Critically, in this literature the actual asset-level costs of owning and operating real estate - which have to be borne by the investor and thus materially affect the net income generated by real property - are unobserved.

Furthermore, by focusing on aggregate capital gains or total returns in the housing market, much of the literature ignores two important dimensions that are particularly relevant for institutional investors:

Idiosyncratic risks. The return on an individual property $r_{i, t}$ may be substantially above or below the aggregate return for its property type $r_{\eta, t}$ for different reasons. First, price appreciation rates may vary across regions, quality categories, etc. Second, "transaction-specific risk" is non-negligible: if property $i$ transacts in year $t$, this may happen at a particularly low or high price $P_{i, t}^{*}$ that is different from the (unobservable) $P_{i, t}$. The idea that in illiquid asset markets there exists a transaction-specific idiosyncratic risk component, which may make observed prices deviate from their expected values, dates back to at least Shiller and Case $(1987) .^{2}$ Third, for any given property and in any given year, the gross income $Y_{i, t}$ may be lower than anticipated (i.e., contracted) or $\operatorname{costs} c_{i, t}$ may exceed expectations for that year. This last source of idiosyncratic risk - and in particular the possibility that annual returns may be volatile because of variation in expenses - has not been explored in prior literature. For example, the discussion of idiosyncratic risks as a potential explanation for the "housing risk premium puzzle" in Jordà et al. (2019b) focuses on individual house price volatility.

Property types other than housing. The global real estate market overall is worth $\$ 228$ trillion; $74 \%$ is residential, $14 \%$ is commercial, and the remainder is agricultural land and forestry (Tostevin, 2017). However, only one third of residential property is investable, compared to two thirds of commercial. ${ }^{3}$ As a result, housing does not begin to represent the investable

\footnotetext{
${ }^{2}$ Recent literature on this topic includes Sagi (2018) and Giacoletti (2019) for real estate and Lovo and Spaenjers (2018) for art.

${ }^{3}$ Most residential real estate is held by entities, operators, and owner-occupiers whose main purpose is not investment. In the U.S. - the largest institutional real estate market worldwide - $16 \%$ of the housing stock is institutionally owned (U.S. Department of Housing and Urban Development, 2015), compared to 78\% of
} 
opportunity set for institutional real estate investors. It is therefore problematic to draw inferences about the investment performance of real estate from the performance of residential property alone. Outside of housing, scholars have studied U.K. agricultural prices (Jadevicius et al., 2018), and commercial property prices in Manhattan (Wheaton et al., 2009) and in the U.K. (Scott, 1996). However, these studies either focus on a narrow geography or a limited number of property types, have a small sample, or lack income data.

\subsection{This Paper}

In our hand-collected data set, which we will present in Section 3, we directly observe transaction prices $\left(P_{i, t}^{*}\right)$, income $\left(Y_{i, t}\right)$, and costs across individual properties of different types. We can thus compute the cost ratio $\left(c_{i, t}\right)$ in every year, and measure the gross income yield $\left(y_{i, t}\right)$ if the property transacts in year $t$. We do not observe an estimate of the property's market value $P_{i, t}$ if it does not trade. However, we can mitigate measurement problems arising from missing market values by further re-arranging Eq. (2) as follows:

$$
\begin{aligned}
r_{i, t} & =\frac{Y_{i, t}}{Y_{i, t-1}} \times \frac{y_{i, t-1}}{y_{i, t}} \times\left[1+\left(1-c_{i, t}\right) y_{i, t}\right]-1 \\
& =(1+\underbrace{g_{i, t}}_{\text {income growth }}) \times \underbrace{\frac{y_{i, t-1}}{y_{i, t}}}_{\text {yield change }} \times[1+\underbrace{\left(1-c_{i, t}\right) y_{i, t}}_{\text {net income yield }}]-1,
\end{aligned}
$$

where $g_{i, t}$ denotes the property-level income growth rate between $t-1$ and $t$. Assuming that average yields on observed transactions $\overline{y_{\eta, t}^{*}}$ are representative for the asset class in that period, we can thus compute a property category's net total return from the observed aggregate income growth rates, changes in gross income yields, and aggregate cost ratios as follows:

$$
r_{\eta, t}=\left(1+g_{\eta, t}\right) \times \frac{\overline{y_{\eta, t-1}^{*}}}{\overline{y_{\eta, t}^{*}}} \times\left[1+\left(1-c_{\eta, t}\right) \overline{y_{\eta, t}^{*}}\right]-1
$$

commercial real estate (Ling and Archer, 2018). In the U.K., the second-largest institutional real estate market, 4 percent of the $£ 6,000$ billion housing stock is held by institutions; in contrast, institutions invest over twelve times that amount, or $£ 490$ billion, in U.K. commercial property (Mitchell, 2017). 
Eq. (4) highlights the importance of income growth in long-term real estate returns. Absent (future) income growth, price increases will imply higher capital gains today, but lower income yields going forward. Absent relative price (i.e., yield) changes, capital gains will equal real income growth rates. Given that in the very long run the average annual yield change cannot be too different from zero - yields cannot increase or decrease ad infinitum - we can expect long-run average capital gains to be relatively close to long-run average income growth rates.

The relationships described in Eq. (4) suggest that accurately measuring rental income growth rates over time is a prerequisite for a meaningful analysis of long-term real estate returns. As discussed before in the context of yield estimation, some prior studies construct market-level housing rent indices. However, as with price indices, adequately controlling for changes in the quality mix of properties over time remains a challenge. The issue may be particularly relevant when indices are based on aggregate national statistics, such as for example in Knoll (2017), who mainly relies on the rent component of cost-of-living and consumer price indices. In a recent contribution, Eichholtz et al. (2018) explicitly tackle the issue of quality adjustments using new historical data and conclude that "most of the increase in housing expenditure that did occur is attributable to increasing housing quality rather than rising rent". 4

\section{Data}

\subsection{Empirical Setting}

Our data set is drawn from the real estate investments held by some of the most prominent Oxford and Cambridge (Oxbridge) colleges. U.K. institutional investors have a long record of investing in real estate, and the oldest Oxbridge college endowments have held property for at least five centuries. For example, King Henry VIII founded Trinity College, Cambridge, and Christ Church, Oxford, in 1546 and conferred on both colleges an expansive agricultural

\footnotetext{
${ }^{4}$ Note that income from ownership of a fixed set of properties may increase even more slowly than the quality-adjusted average rental income in the broader economy. This would be the case if the income associated with a property tends to jump when ownership changes, or if newly leased properties have higher average rents even after adjusting for their higher quality. Such scenarios are not unlikely if there exist constraints on the ability of owners to update rents, for example through legal or contractual limits on rent reviews.
} 
real estate portfolio. At the start of the twentieth century, their portfolios consisted almost exclusively of real estate (Chambers et al., 2013). ${ }^{5}$ Notwithstanding diversification into stocks and bonds in the twentieth century, the oldest and wealthiest of the Oxbridge colleges still allocate over $40 \%$ of their endowment to real estate today (Cambridge Associates, 2018).

By the early decades of the twentieth century, the investment and property portfolios of Oxbridge colleges were being professionally managed. The senior bursar - equivalent to the chief financial officer and chief investment officer rolled into one- of a college was expected (with the help of professional advice) to set investment strategy, and to execute that strategy in buying and selling both real estate and financial securities. This is particularly apparent in the cases of Trinity and King's College in Cambridge (Nicholas (1960), Neild (2008), Chambers et al. (2013)).

\subsection{Data Collection}

We study King's College, Cambridge (founded in 1441), and Trinity College, Cambridge, as well as Christ Church and New College, Oxford (all founded in 1379). These colleges are among the oldest and wealthiest Oxbridge colleges at the beginning of the twentieth century (Dunbabin, 1975). We begin our data collection in 1901 and end in 1970. We start in 1901 for two reasons. First, prior to the late nineteenth century, colleges were forbidden by statute from freely buying or selling property and were restricted in their ability to raise rents and develop their estates (Neild, 2008). Second, by the turn of the century, beneficial leases charging below-market rents had been eradicated and all properties were let at market rent (Dunbabin, 1975). The year 1970 is a natural stopping point for our analysis as higher-quality estimates on the performance of real estate exist from the 1970s onward. Moreover, access to archival records is restricted after this date, due to the ongoing commercial sensitivity of the data.

We focus on the investment properties held in college endowments and ignore operational properties outside the endowments, which are typically not for sale and are not let at market rents. We compile an unbalanced panel data set of property-year observations on rental income

\footnotetext{
${ }^{5}$ In contrast, the largest U.S. university endowments allocated only $10 \%$ of their assets to direct real estate in the early twentieth century (Goetzmann et al., 2010). U.S. institutional investors did not in general begin to make a substantial allocation to real estate until the 1970s and 1980s (Eagle, 2013)
} 
received, costs incurred, and transaction values realized, alongside a number of property and transaction characteristics, as follows. ${ }^{6}$

For King's College, Cambridge, we collect annual property-level realized rental income and costs incurred over the years 1901-1970 from the annual volumes of the so-called "Mundum Books". Transactions of properties over the same period are found in the "Ledger Books". We record transaction type (purchase or sale), transaction amount, and year. These records further allow us to identify partial transactions (part of a property) and portfolio sales (more than one property), as well as instances where the use of the property has changed - often agricultural land being sold with a permission for residential development. Where available, we collect information on location, size, and other characteristics of the property. We manually match income and cost records on the one hand with transaction records on the other hand by the common property name.

Figure 1 presents an example of a matched transaction for King's College. Subfigures 1A and 1B show the income and cost record for a farm property called "Middle Cliston" located in the village Sampford Courtenay in the county of Devon. In the financial year 1926, the property generated a rental income of $£ 152$ in two semi-annual payments, while the costs (including for "ironmongery" and a "carpenter") amounted to slightly more than $£ 19$ in total. Subfigure 1C shows part of the document recording the transaction for the same property, which was sold in 1927 for $£ 2,552$.

\section{$\overline{\text { FIGURE } 1 \text { ABOUT HERE. }}$}

\footnotetext{
${ }^{6} \mathrm{~A}$ few general points about our data collection are worth mentioning. First, for all colleges, we exclude nonstandard rent types such as rentcharges, wayleaves, and contracts related to trust estates. Second, where a cost record relates to a group of properties (e.g., a row of houses on the same street), we split these costs equally across the properties. Third, both for King's and Trinity College, some properties show substantially lower income in 1926; for Trinity we also observe a temporary jump in income in 1925 for some properties. These patterns seem related to changes in the accounting methods adopted by those colleges. Appendix B explains how we treat the income records for these years. Fourth, across all colleges, the recorded transaction year may not coincide with the first or last calendar year for which we record an income or cost observation. One reason is that a property may be vacant for some months (or even years) leading up to a sale or remain vacant for some time after it has been purchased by a college. In such cases, we match the transaction to the last or first available income observation. Fifth, it is possible for all colleges to acquire and dispose of properties through means other than purchases and sales (e.g., through bequests and exchanges). Our records do not capture such acquisitions or dispositions.
} 
For Trinity College, Cambridge, we collect annual realized property-level rental income and costs incurred from the Rent Books over the period 1901-1970. Unfortunately, due to a missing volume in the archives, records are missing for most residential properties for the period 1966-1970. Unlike at King's, annual income and cost data is reported by tenant name, instead of property name. When several tenants occupy a property, we aggregate income across all tenants in the property in a given year. We collect data on transactions over the same period from the "Sealed Books". Transactions are reported by property name. Matching tenant-level income data with property-level transaction data is challenging because there is no one-to-one relation between the property on which the college receives rent from a tenant and the property transacted. As a result, we match the Trinity income and transaction records by identifying unique property characteristics. For both Cambridge colleges, we match in excess of $50 \%$ of the recorded transactions to properties in the income and cost data.

For Christ Church and New College in Oxford, there are some gaps in the archival records, particularly with respect to rents, due to volumes being destroyed or lost. For these two colleges, we collect data on transactions over the period $1901-1970 .^{7}$ We then collect income and cost data for the year of the transaction and, in case of a sale (purchase), two years before (after). We also obtain information on contractual income - in addition to realized income - which is available for certain years. In case of missing records for realized income, we use contractual income whenever possible. Data on transactions, annual property-level realized and contractual rental income as well as costs incurred are obtained from the sources outlined in Appendix A, which also outlines the exact years for which realized and contractual income records are available. Properties are identified by name in all sources, allowing us to match income and cost as well as transaction records. Property and transaction characteristics are collected from all sources as available.

\footnotetext{
${ }^{7}$ On occasion the transaction records include a property, such as a large piece of farmland or a residential property with multiple tenants, which is sold not in a single transaction but in a series of transactions in the same year. In particular, Christ Church owned a large number of residential properties in Kentish Town which were highly homogeneous, earned similar rents and were transacted in close succession at similar prices. In such instances, we merge all related transactions into a single transaction with a unique identifier and aggregate all the associated rental income streams into one.
} 


\subsection{Resulting Data Sets and Descriptive Statistics}

The data collection described above produces two data sets. First, a larger database of 48,613 annual property-level observations on income, cost and property characteristics, mainly based on records from King's and Trinity College. The unit of observation is thus a unique property-year combination, i.e., property $i$ in year $t$. The data cover 2,949 different properties. ${ }^{8}$ Second, a smaller database of 1,972 matches between the just-mentioned income data and the transaction records, which will be used in our estimation and analysis of income yields. This database includes income and cost data as well as corresponding property and transaction characteristics. Here the unit of observation is a property-transaction combination, i.e., the purchase or sale of property $i$ in transaction $x$. (Every transaction is of course associated with a certain year t.) Our matched property records correspond to 1,542 distinct transactions.

Table 1 shows a number of different frequency tables for the income database. More specifically, it shows the number of property-year income and cost observations - and the number of distinct properties that these observations relate to-by decade (Panel A), by college and property type (Panel B), and by region of the U.K. (Panel C). Our data are spread evenly over time with an average of approximately 7,000 property-year observations per decade. Based on the qualitative descriptions provided in the archival records, we classify properties into one of four main types. We maintain a property's initial classification throughout its life in the sample. "Agricultural" refers to land used for farming and represents approximately $50 \%$ of the sample. "Commercial" refers to any property let to a retail, industrial or other commercial business and represents $13 \%$ of our income observations. "Residential" refers to any residential property or building and contributes about $33 \%$ of the data. "Other"- by far the smallest category representing $4 \%$ of the sample - refers to schools, government buildings, etc. For the Oxford colleges, our focus on years surrounding transactions of course implies much smaller

\footnotetext{
${ }^{8}$ This is after accounting for the fact that properties sometimes undergo structural changes, e.g. a large agricultural property may be subdivided into smaller parcels, or a number of smaller parcels may be merged into a larger property. In such cases, we assign new property identifiers when the change occurs.

${ }^{9}$ Properties with mixed uses are classified as much as possible under one of the three main types, with priority given to agricultural and otherwise to commercial. Where the necessary information is not available, mixed-use properties are classified under the "other" category.
} 
data samples. Table 1 also shows that the Oxbridge colleges were diversified geographically, although the largest portfolio shares were located in the East and South of England.

\section{TABLE 1 ABOUT HERE.}

Table 2 reports on the composition of our sample of matched property-transaction observations. It thus shows the availability of income observations as does Table 1 , but we now only consider property-year combinations matched to a transaction. Observed and matched property sales outnumber purchases by a factor of almost 3:1. ${ }^{10}$ Panels A-C summarize the distribution of matched property-transaction records by purchase and sale over time, by college, and by property type. We observe the highest trading volume in agricultural real estate, particularly in terms of sales. The final column in each panel shows the number of distinct transactions, which may comprise multiple transacted properties (due to portfolio transactions), corresponding to each row. In Panel D, we show the distribution of matched property-transaction observations over transactions of one (complete) property, partial transactions, and portfolio transactions of multiple properties. For portfolio transactions, the number of distinct transactions is by construction lower than the number of property-transaction combinations.

\section{TABLE 2 ABOUT HERE.}

Table 3 provides summary statistics on nominal and real income and transaction prices over time. We use inflation data from Dimson et al. (2019) to convert nominal values into real terms. In Panel A, we report for each decade the number of non-missing gross income and net income (i.e., income less costs) observations, together with means and medians. In real terms, both mean gross and net income decreased substantially after the first decade of the twentieth century, but increased in later decades. However, median real income only bottomed out in the 1960s. In Panel B, we show for each decade the mean and median purchase and sale price levels. In this panel, the unit of observation is a transaction, not a property-transaction combination, so there is no double-counting of portfolio transactions. Mean purchase prices are substantially higher

\footnotetext{
${ }^{10}$ However, note that the colleges may have acquired properties through other methods than outright market purchases.
} 
than sale prices in all decades. Although mean prices are somewhat higher at the end of our sample period than in the beginning, there exists no monotonic trend over our sample period.

\section{TABLE 3 ABOUT HERE.}

\section{Results}

\subsection{The Evolution of Real Estate Portfolios}

We start our empirical analysis by studying the evolution of the property portfolios of King's and Trinity College, for which we have a near-complete history of holdings and associated rental income. Figure 2 graphs the evolution of the two portfolios. Subfigures 2A and 2B show the timeseries of the number of income-generating properties by property type for both colleges. Subfigures $2 \mathrm{C}-2 \mathrm{~F}$ display the evolution of nominal and real (inflated to year-1970 British pounds) gross income along the same dimensions, while subfigures $2 \mathrm{G}-2 \mathrm{~J}$ repeat the exercise for net income.

\section{FIGURE 2 ABOUT HERE.}

As can be clearly seen, the portfolios of these institutions have always encompassed all three property types. At the start of the twentieth century, both colleges were heavily concentrated in agricultural real estate, which generated more than three-quarters of total gross income. This allocation reflects the nature of their original endowments centuries earlier and a lack of trading over the intervening period. Yet, from the little that is known of other institutional property portfolios at the start of the twentieth century, a heavy portfolio allocation towards agricultural real estate was not unusual (Dunbabin, 1975). Subsequently, over our sample period there was a significant shift for both colleges in portfolio holdings - both in terms of number of properties and total rental income - away from agricultural real estate in favor of commercial real estate. So much so that by 1970 commercial is by far the most important property type held by both institutions. The growing importance of commercial real estate is most striking when studying the evolution of income rather than the number of properties; average income is of course much higher for a commercial property than for a residential house. Our findings underscore the need 
to include property types other than housing in order to produce an accurate estimation of the long run performance of the entire real estate asset class.

\subsection{Gross income growth over time}

In the previous subsection we see that aggregate rental income by property type shifts over time at least in part due to the fluctuations in the number of properties in the college portfolios. As a result, average property quality is changing from year to year. In order to estimate quality-controlled (gross) income indices over our sample period, we proceed as follows. In every year $t$, we consider all Cambridge properties that are present in our income database both in year $t-1$ and in year $t .^{11}$ Next, we compute for every year $t$ the percentage change in aggregate income. Finally, we chain-link the estimated time-series of income growth rates. The resulting index thus explicitly controls for changes in the quality mix of the portfolio of properties over time, in a way similar to repeat-sales regressions in the estimation of capital gains on properties. ${ }^{12}$

Figure 3 presents the resulting indices, both at the aggregate level and for each of the three main property types separately. Subfigure 3A shows the nominal indices, while Subfigure 3B depicts the deflated indices alongside annual inflation rates. Note that as reported in Panel $\mathrm{C}$ of Table 1, the property portfolios of the two Cambridge colleges are well-diversified geographically across the English regions with significant exposure to the economically more prosperous South. As a result, the annual time-series of their combined rental income is broadly representative of the overall U.K. real estate market.

\section{FIGURE 3 ABOUT HERE.}

Subfigure 3A shows that nominal income remained almost constant over the first four decades of our sample period and only starts to increase after WWII. After correcting for

\footnotetext{
${ }^{11}$ To avoid mis-measurement of income trends due to properties that have just entered or are about to exit the portfolio, we exclude from the analysis any properties for which we observe a transaction between $t-2$ and $t+1$, and properties that first appear in the data set in $t-2$ or $t-1$ or last appear in the data set in $t$ or $t+1$.

${ }^{12}$ To interpret the resulting rental income index as a constant-quality one, we of course need to assume that the expenditures on repairs and maintenance - which we will analyze later - are sufficient to avoid property degradation.
} 
inflation, Subfigure 3B presents a very different picture where real income growth exhibits substantial time-series variation. First, real rental income decreased dramatically for all property types during WWI and until 1920, and then rebounded in the early 1920s. This reflects the impact of high inflation during the war and its immediate aftermath followed by subsequent price deflation induced by a policy of returning the pound sterling to the gold standard. Second, residential income continued to grow until the early 1930s, but income for all property types decreased in the second half of the 1930s, as inflation started to rise again. Third, between 1940 and 1970, we see very little real income growth, except for agricultural real estate in the $1960 \mathrm{~s} .{ }^{13}$

Table 5 presents annualized nominal (in Panel A) and real (in Panel B) income growth rates over our complete sample period 1901-1970, and three different subperiods: pre-WWI, 1914-1945, and post-WWII. As noted before, nominal income grew fast after WWII; the average growth rate when considering the complete portfolios is $4.6 \%$. Yet, the equivalent number in real terms is only $0.6 \%$. Considering the full sample period, we estimate that real income growth is close to zero for all property types. The annualized real growth rates computed based on the indices shown in Subfigure 3B are $0.0 \%$ for agricultural, $-0.8 \%$ for commercial, and $-1.0 \%$ for residential real estate. These results imply that the colleges can have achieved capital gains in excess of inflation on their real estate investments only if gross income yields declined.

$$
\text { TABLE } 5 \text { ABOUT HERE. }
$$

\subsection{Gross Income Yields}

We now turn to estimating gross income yields from our data set, based on the matched transactions-rental income database. We exclude "other" property types, furnished lettings, partial transactions, and small transactions defined as below $£ 500$ in year-1970 terms (about $£ 5,500$ at the end of 2018). For a property bought (sold) in year $t$, we use the maximum real income generated by the property over the calendar years $t$ until $t+2(t-2$ until $t)$. We consider these two-year windows before (after) a disposition (acquisition) to minimize the

\footnotetext{
${ }^{13}$ Rent controls may have held back rental income growth over certain parts of our sample period (e.g., 1915-1923, 1939-1957) (Knoll, 2017).
} 
effect of temporary voids on income and present an income estimate that is representative for the stabilized operation of a given property. (For instance, properties may be vacated by the occupants prior to a disposition. Alternatively, there may be an initial lease-up period just after the completion of an acquisition.) We exclude cases where this maximum equals zero. We then divide real income by the real transaction price. For portfolio transactions (i.e., a set of properties purchased or sold by one of our colleges in a single transaction), we observe the transaction price for the entire portfolio. To compute yields on portfolio transactions, we aggregate income over all properties reported as being bought or sold in the same transaction. We then classify the transaction under a single property type (agricultural, commercial, or residential) according to the property in the portfolio that generates the highest income in the year of the transaction. We winsorize our yield estimates at the $5^{\text {th }}$ and $95^{\text {th }}$ percentile.

Panel A of Table 6 presents summary statistics for the gross income yields estimated over the same subperiods shown in Table 5. We find equal-weighted (value-weighted) mean yields before costs of $4.1 \%-5.4 \%(3.4 \%-5.2 \%)$. Panels B-D of Table 6 repeat the same exercise for each of the main property types, separately. The relatively low yields for residential real estate and relatively high yields for commercial real estate after WWII are particularly striking.

\section{TABLE 6 ABOUT HERE.}

Subfigure 4A provides summary statistics for the estimated income yields (equal-weighted and value-weighted mean, median, first and third quartile), measured over moving five-year periods. We are showing the statistics over moving intervals as the samples can get small in any given individual year, especially in the early decades of our sample time frame. In most periods, the mean gross income yields are between $4 \%$ and $6 \%$. Taking a simple average over all periods, we find a value of $4.7 \%$ for the equal-weighted mean yields ( $4.8 \%$ for the value-weighted mean yields). Our estimates suggest that mean yields exceed $6 \%$ in the 1930 s, a period during which deflation caused a temporary increase in real rental income (cf. Figure 3). By contrast, the

results reported indicate that mean yields drop below $4 \%$ before WWI and revert to the same levels near the end of our sample period. 


\section{$\overline{\text { FIGURE } 4 \text { ABOUT HERE. }}$}

Subfigure 4B presents equal-weighted means by property type over moving ten-year periods. The mean yields average to $4.7 \%$ for agricultural, $5.7 \%$ for commercial, and $4.5 \%$ for residential real estate over all periods. Our estimated yields for the different property types move in a narrow range until WWII. Thereafter, yields for agricultural and residential real estate trend downwards, while yields for commercial real estate trend in the opposite direction. As Figure 3 depicted, real income for residential properties in the 1960s was in line with previous decades, while agricultural properties exhibited substantial income growth in the same decade. The lower yields at the end of the sample period thus point to significant real price rises for these property types. By contrast, the increasing yields on commercial real estate in the last two decades of our sample period imply substantial real price decreases then.

Our granular data on income and transaction prices allow us to document cross-sectional variation in realized yields across individual real estate assets and the different property types. For example, Subfigure 4A exhibits an average difference of about 3 percentage points between the first and the third quartiles of income yields for all properties, even in times when the different property types have comparable average yields. This finding highlights the importance of idiosyncratic risks in real estate investments. First, some properties will generate less income than expected. Second, at the time of purchase and sale, the prices for some properties will be lower or higher than anticipated.

Table 7 presents output from a regression with transaction-level yields as the dependent variable, estimated as a function of property and transaction characteristics. The results reported suggest that purchases (rather than sales), portfolio transactions, and commercial properties are associated with higher yields, i.e., lower prices relative to the income stream. We estimate that a change in use around the time of a sale, which typically represents an agricultural property that can now be developed for residential or commercial use, is correlated with lower yields, i.e., a higher relative price. Despite the inclusion of a comprehensive set of covariates, as well as fixed effects for college identity, geographical region, and transaction time, the $R^{2}$ of the regression is only $20.0 \%$, implying that a large proportion of the total variation in 
yields remains unexplained. These regression results reinforce the importance of idiosyncratic risk factors in the pricing of real estate investment assets.

\section{TABLE 7 ABOUT HERE.}

\subsection{The Impact of Costs}

In what follows, we analyze the extent to which costs reduce realized income yields. The college rent books show that the different types of cost incurred in managing their properties, namely, repairs, improvements, property taxes and rates, payments to estate agents or brokers, and insurance. To assess their importance, we compare costs and realized income aggregated across the two Cambridge colleges. Subfigure 5A displays the results both aggregated over all properties and by property type. When considering the average across years for all property types, we document a mean cost-to-income ratio of $35 \%$. In many years the ratio ranges between $30 \%$ and $40 \%$, but we document substantial variation outside this range. Commercial real estate is associated with the lowest average cost ratio $(28.2 \%)$, especially in the final decades of the study period. Residential (36.7\%) and especially agricultural real estate (43.4\%) have higher relative costs, meaning that net yields will deviate more from gross yields for these property types.

\section{$\overline{\text { FIGURE } 5 \text { ABOUT HERE. }}$}

For Trinity College, we have annual rent book summaries that allow us to break down total costs into different categories. We show the results in Subfigure 5B. Improvements represent the largest cost category, especially after World War II.

Figure 5 focuses on aggregate costs. However, there exists substantial variation across properties and over time in the extent to which costs depress net income. The upshot is that property-level net income streams will be much more volatile than gross income streams. This finding is illustrated in Figure 6. We show for every year the distribution of property-level gross or net income changes over the prior year across five categories: a decrease of $10 \%$ or more, a decrease of less than 10\%, no change, an increase of less than 10\%, or an increase of $10 \%$

or more. Subfigure 6 A points to the relative stability of gross income streams; sharp decreases 
or increases are relatively uncommon. However, in Subfigure 6B, we see a completely different story when taking into account costs. When pooling data across years, we estimate that the probability of a property-level decrease in net income of $10 \%$ or more (and of an increase in net income of $10 \%$ or more) exceeds $20 \%$. Ignoring costs therefore leads to a substantial underestimation of the volatility of real estate income streams and thus total net returns.

$$
\text { FIGURE } 6 \text { ABOUT HERE. }
$$

\subsection{Capital Gains and Net Total Returns}

Our findings allow us to estimate capital gains and the net total rate of return on real estate. First consider housing. We have documented an average income yield of $4.5 \%$ over the sample period, with an average cost-to-income ratio of $36.7 \%$. These estimates imply an average net income yield of about $2.8 \%$. Following Section 2, the total real capital gain implied by the start and end values of both the real income index (shown in Subfigure 3B) and the gross yield series can be computed as follows:

$$
k_{\eta, 1901 \rightarrow 1970}=\left(1+g_{\eta, 1901 \rightarrow 1970}\right) \times \frac{\overline{y_{\eta, 1901}^{*}}}{\overline{y_{\eta, 1970}^{*}}}-1 .
$$

We use the first (last) available decade-level average yield from Subfigure 4B as a proxy for $\overline{y_{\eta, 1901}^{*}}\left(\overline{y_{\eta, 1970}^{*}}\right)$. If we then annualize the total capital gain given by Eq. $(5)$, we find a geometric average rate of real price appreciation of $0.2 \%$ between 1901 and 1970 for residential real estate. Our estimate of the annualized real net total return to housing over our sample period is thus approximately 3.0\%. Table 8 presents our estimated decomposition of the annualized net total returns for each of residential, agricultural and commercial real estate. (For commercial real estate, the initial yield is computed starting in 1911.) In the case of the latter two property types, we document annualized net total returns of $3.8 \%$ and $2.3 \%$ in real terms, respectively.

\section{TABLE 8 ABOUT HERE.}

Over the same time period 1901-1970, annualized real total returns to U.K. government bonds and equities were $0.1 \%$ and $5.0 \%$, respectively, according to Dimson et al. (2019). The 
performance of real estate thus falls in between these two more traditional assets. Dimson et al. (2011) perform a decomposition of long-run equity returns for the period 1900-2010 similar in spirit to ours. The mean total real equity return for 19 countries largely arises from the average dividend yield over the sample period, with the real dividend growth rate slightly below zero on average and a modest contribution from the decline in dividend yields (rise in valuations) over time. We observe a qualitatively similar decomposition in our real estate returns analysis, especially for agricultural and residential real estate.

\section{Discussion}

Our study is the first to provide a property-type specific breakdown of total returns to real estate investments in the long run. Our estimates suggest that all real estate types generated a real net return of less than 4\% per year over the 1901-1970 period. In this section, we discuss our findings in the context of the existing empirical evidence.

Residential real estate. Most of the existing empirical work on the performance of real estate investments relates to the history of the housing market. We can directly compare our index of rental income to, first, the rental index in Jordà et al. (2019a) based on Knoll (2017), and, second, the quality-adjusted real rent index for London estimated in contemporaneous work by Eichholtz et al. (2018). We show the different series in Figure 7 for all available years starting in 1901. Note that Eichholtz et al. (2018) use a methodology similar in spirit to ours for most of the overlapping time period, relying on repeated individual rent observations taken from the archives of actual real estate investors. By contrast, the estimates used in Jordà et al. (2019a) are constructed using aggregated data (on average rents and on the rent component in consumer price indices) that do not adjust for variation in quality. Importantly, the primary data are particularly thin for the 1939-1954 period; Knoll (2017) even notes that "to the best of [her] knowledge, no data on rents exists between 1946 and 1954" (p. 247). ${ }^{14}$

\footnotetext{
${ }^{14}$ We represent their rent index as derived from the house price index and rental yields as used in Jordà et al. (2019a). This income index shows a gap over World War II as the authors do not have rental yield estimates for those years.
} 


\section{$\overline{\text { FIGURE } 7 \text { ABOUT HERE. }}$}

Our estimate of $-1.0 \%$ annual real gross income growth in residential property over the 1901-1970 period is very close to the estimate of Eichholtz et al. (2018), who indicate an annualized growth rate of real housing rents in London of $-1.1 \%$ over the same period. By contrast, the index of Jordà et al. (2019a) grows by $+0.8 \%$ per year on average. The difference mainly comes from a very substantial gap in estimates for the period between the start of World War II and the late 1950s. Over the years 1938-1957, we document an annualized real income growth rate of $-3.2 \%$, compared to $-3.7 \%$ in Eichholtz et al. (2018) but $+3.3 \%$ in Jordà et al. (2019a). After this period, the indexes of Eichholtz et al. (2018) and Jordà et al. (2019a) show very similar dynamics and long-run average growth rates.

The stark gap in income growth estimates between our results and Jordà et al. (2019a) are reflected in substantial differences in the income yield estimates for the post-WWII years. In Panel D of Table 6, we reported a value-weighted mean gross yield for housing of $5.2 \%$ for the 1914-1945 period and 2.9\% for the 1946-1970 period. Assuming a constant cost ratio of $36.7 \%$ as before, this implies mean net yields of $3.3 \%$ and $1.8 \%$, respectively. Taking averages over the annual yields reported by Jordà et al. (2019a) results in net yield estimates of $3.8 \%$ over the period 1914-1939 and 4.6\% over the period 1946-1970. It is thus mainly the estimates for the decades following the end of World War II that explain why we report an average net yield of $2.8 \%$ for residential real estate over 1901-1970 in Table 8, while Jordà et al. (2019a) come to an average net yield of $4.1 \%$ over the same period.

In terms of capital gains, our findings are consistent with prior research suggesting limited long-run price appreciation. Our estimate of a $0.2 \%$ average real capital gain over the 1901-1970 period is only slightly lower than that in Knoll et al. (2017), whose index values imply an annualized real price growth rate of $0.3 \%$ over the same period.

In sum, the results we present based on our granular property-level information indicate that residential property produced significantly lower levels of actual net income relative to property prices - and thus lower total returns - than suggested in prior work. 
Agricultural and commercial real estate. Benchmarking our performance estimates in the case of the other two types of real estate is more problematic due to a lack of prior estimates. Yet, where such data exist, the consistency with our own findings is reassuring. For agricultural property, our income and yield dynamics imply substantial price drops in the first two decades of the twentieth century and significant price appreciation in the 1960s. These results are in line with the estimates reported in Spaenjers (2016) and Jadevicius et al. (2018). ${ }^{15}$ For commercial real estate, the higher yield estimates we present at the end of our sample period are consistent with the earliest-available data on U.K. commercial property provided by IPD. For the end of our sample period, we estimate net yields around 5\% — based on gross yields of 7 to $8 \%$ (see Figure 4) and an average cost ratio of about 28\% (see Table 8) - similar to those reported by IPD.

\section{Conclusion}

In this paper, we construct a unique data set from the archival records of a group of important U.K. institutional real estate investors - the endowments of four large Oxbridge Colleges - which contains granular information on realized rental income, costs, and transaction prices at the level of individual properties over the period 1901-1970. This data set allows us to estimate not only realized income growth over time, but also income yields, cost-to-income ratios, capital gains, and net total returns.

Our empirical results can be summarized as follows. First, long-term real rental income growth is close to zero for all major property types. Second, average gross yields fluctuate around $5 \%$ for most of the study period. Significant yield compression in agricultural and residential real estate occurred during the last two decades of our sample period (as house and land prices where increasing), while commercial yields showed the opposite trend. Substantial cross-sectional and time-series variation in gross yields across transacted properties that remains unexplained by a regression model highlights the high level of idiosyncratic risk associated with direct real estate investments. Third, operating costs lower gross yields by $30 \%-40 \%$ and significantly increase the

\footnotetext{
${ }^{15}$ Temporal variation in average quality is arguably less of a concern for farmland.
} 
volatility of the (net) income from real estate. Fourth, our estimates on income and yield dynamics imply very limited long-run capital gains, and annualized real net total returns of less than $4 \%$ for the different property types. In all, our results suggest that the (risk-adjusted) investment performance of direct real estate assets in the long run is less attractive than previously thought. 


\section{References}

Brounen, D., P. Eichholtz, S. Staetmans, and M. Theebe (2014): "Inflation Protection from Homeownership: Long-Run Evidence, 1814-2008," Real Estate Economics, 42(3), 662689.

Cambridge Associates (2018): "Cambridge University Bursars Meeting: Market Update and Asset Allocation," Survey, Cambridge Associates.

Chambers, D., E. Dimson, and J. Foo (2013): Keynes, King's, and Endowment Asset Management, pp. 127-150. University of Chicago Press.

Dimson, E., P. Marsh, and M. Staunton (2002): Triumph of the Optimists, 101 Years of Global Investment Returns. Princeton University Press.

(2011): "Equity Premiums around the World," in Rethinking the Equity Risk Premium, ed. by P. B. Hammond Jr., M. L. Leibowitz, and L. B. Siegel, pp. 32-52. The Research Foundation of CFA Institute.

(2018): Global Investment Returns Yearbook 2018. Credit Suisse Research Institute.

(2019): Global Investment Returns Yearbook 2019. Credit Suisse Research Institute.

Dunbabin, J. P. D. (1975): "Oxford and Cambridge College Finances, 1871-1913," Economic History Review, 28(4), 631-647.

EAgle, B. (2013): "The Institutionalization of the U.S. Commercial Real Estate Market," Discussion paper, Portland State University Center for Real Estate Quarterly.

Eichholtz, P., M. KorevaAr, and T. Lindenthal (2018): "500 Years of Urban Rents, Housing Quality and Afordability," Working paper, Maastricht University.

Eichholtz, P., S. Straetmans, and M. Theebe (2012): "The Amsterdam Rent Index: The Housing Market and the Economy, 1550-1850," Journal of Housing Economics, 21(4), 269-282.

Eichnoltz, P. M. (1997): "A Long Run House Price Index: The Herengracht Index, 1628-1973," Real Estate Economics, 25(2), 175-192.

Favilukis, J., S. C. Ludvigson, and S. Van Nieuwerburgh (2017): "The Macroeconomic Effects of Housing Wealth, Housing Finance, and Limited Risk Sharing in General Equilibrium," Journal of Political Economy, 125(1), 140-223.

Ghent, A. C., W. N. Torous, and R. I. Valkanov (2018): "Commercial Real Estate as an Asset Class," Working paper.

Giacoletti, M. (2019): "Idiosyncratic Risk in Housing Markets," Working paper, SSRN.

Giglio, S., M. Maggiori, K. Rao, J. Stroebel, and A. Weber (2018): "Climate Change and Long-Run Discount Rates: Evidence from Real Estate," Discussion Paper 17-22, Chicago Booth. 
Goetzmann, W., J. Griswold, And T. Yung-FAng (2010): "Educational Endowments in Crises," Journal of Portfolio Management, 36(4), 112-123.

Gyourko, J., C. Mayer, and T. Sinai (2013): "Superstar Cities," American Economic Journal: Economic Policy, 5(4), 167-199.

Hudson-Wilson, S., J. N. Gordon, F. J. Fabozzi, M. J. P. Anson, and S. M. Giliberto (2005): "Why Real Estate?," Journal of Portfolio Management, 32, 12-22.

Jadevicius, A., S. Huston, A. Baum, and A. Butler (2018): "Two Centuries of Farmland Prices in England," Journal of Property Research, 35(1), 72-94.

Johnston, L., and S. Williamson (2019): "What Was the U.S. GDP Then?," Discussion paper, Measuring Worth.

Jordà, O., K. Knoll, D. Kuvshinov, M. Schularick, and A. M. Taylor (2019a): "The Rate of Return on Everything, 1870-2015," Quarterly Journal of Economics, forthcoming.

JordÀ, O., M. Schularick, And A. M. Taylor (2019b): "The total risk premium puzzle," Working paper.

Jorion, P., and W. N. Goetzmann (1999): "Global Stock Markets in the Twentieth Century," Journal of Finance, 54(3), 953-980.

Knoll, K. (2017): "Our Home in Days Gone By: Housing Markets in Advanced Economies in Historical Perspective," Ph.D. thesis, Free University of Berlin.

Knoll, K., M. Schularick, and T. Steger (2017): "No Price Like Home: Global House Prices, 1870-2012," American Economic Review, 107(2), 331-353.

Ling, D., And W. Archer (2018): Real Estate Principles: A Value Approach. McGraw-Hill Education, Fifth edn.

Lovo, S., And C. Spaenjers (2018): "A Model of Trading in the Art Market," American Economic Review, 108(3), 744-774.

Mitchell, P. (2017): "The Size And Structure of the UK Property Market," Discussion paper, IPF Research.

NeILD, R. (2008): Riches and Responsibility: The Financial History of Trinity College, Cambridge. Granta Editions.

Nicholas, T. (1960): "The Endowments of Trinity College, 1914-59," Review, Trinity College.

Nicholas, T., And A. Scherbina (2013): "Real Estate Prices During the Roaring Twenties and the Great Depression," Real Estate Economics, 41(2), 278-309.

SAGi, J. (2018): “Asset-Level Risk and Return in Real Estate Investments," Technical Report, UNC Chapel-Hill.

Scott, P. (1996): The Property Masters: A History of the British Commercial Property Sector. Taylor \& Francis. 
Shiller, R. J. (2000): Irrational Exuberance. Princeton University Press.

Shiller, R. J., And K. E. CASe (1987): "Prices of Single-Family Homes Since 1970: New Indexes For Four Cities," New England Economic Review, 5(Sep), 45-56.

Spaenjers, C. (2016): "The Long-Term Return to Durable Assets," in Financial Market History, ed. by D. Chambers, and E. Dimson. CFA Institute.

Tostevin, P. (2017): "How Much Is the World Worth?," Discussion paper, Savills.

U.S. Department of Housing and Urban Development (2015): "Rental Housing Finance Survey," Discussion paper, U.S. Census Bureau.

Wheaton, W. C., M. S. Baranski, and C. A. Templeton (2009): "100 Years of Commercial Real Estate Prices in Manhattan," Real Estate Economics, 37(1), 69-83. 
Figure 1. Example of data

This figure illustrates our data collection. Subfigures 1A and 1B show the year-1926 income and costs for a farm property called "Middle Cliston" (source: King's College Archives, KCAR/3/3/1/1/26 folio 24). Subfigure $1 \mathrm{C}$ shows an excerpt from the year-1927 transaction record for the same property - a sale at $£ 2,552$ (source: King's College Archives, KCAR/4/1/1/1926/1 opening 75).

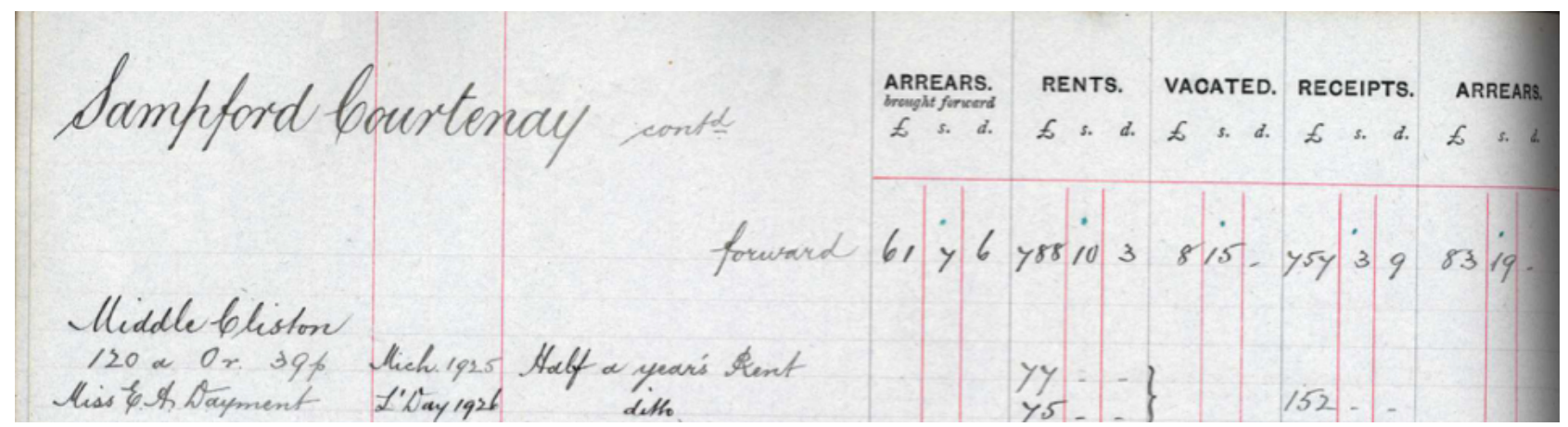

(A) Income

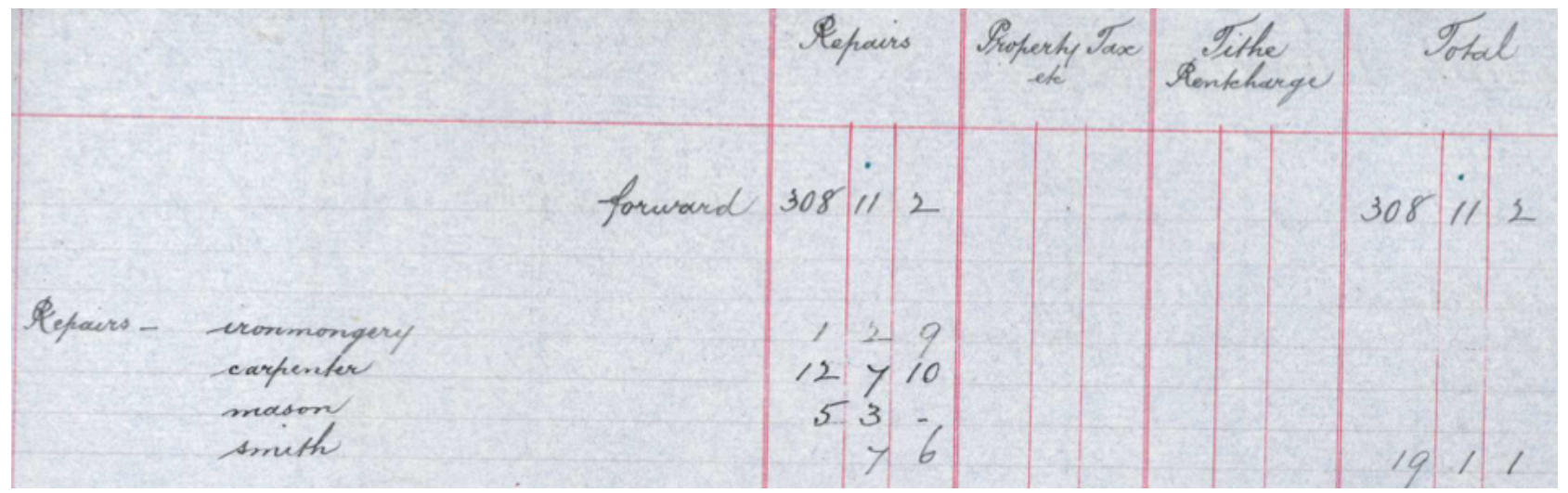

(B) Costs

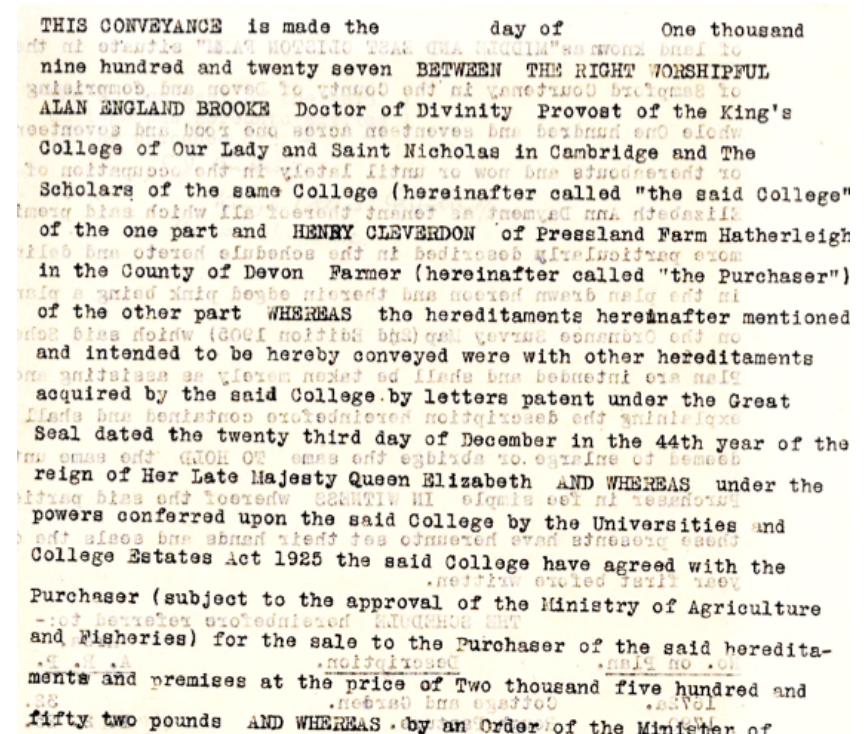

(C) Transaction record 
Figure 2. Evolution of portfolios

This figure illustrates the evolution of the King's and Trinity College portfolios over our sample period in terms of numbers of properties (subfigures $2 \mathrm{~A}$ and $2 \mathrm{~B}$ ), nominal gross income (subfigures $2 \mathrm{C}$ and $2 \mathrm{D}$ ), real gross income (subfigures $2 \mathrm{E}$ and $2 \mathrm{~F}$ ), nominal net income (subfigures $2 \mathrm{G}$ and $2 \mathrm{H}$ ), and real net income (subfigures 2I and 2J). Each figure shows the relative importance of agricultural, commercial, residential, and other real estate. Note that for Trinity we do not have exhaustive data on its residential real estate holdings for the period 1966-1970 due to a missing volume in the archival records.

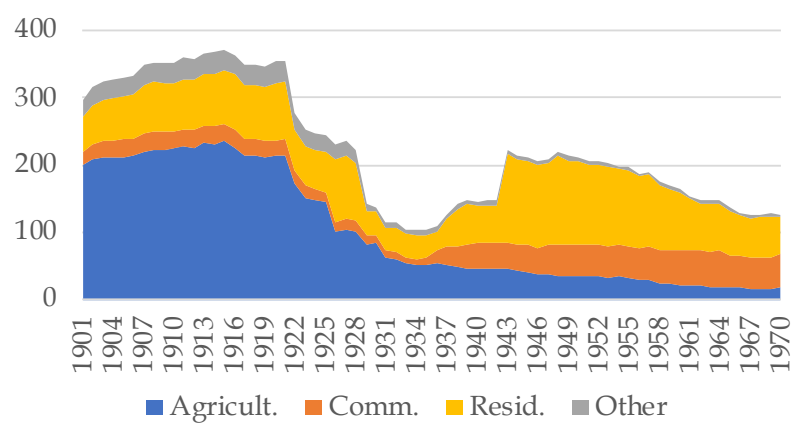

(A) King's: number of properties

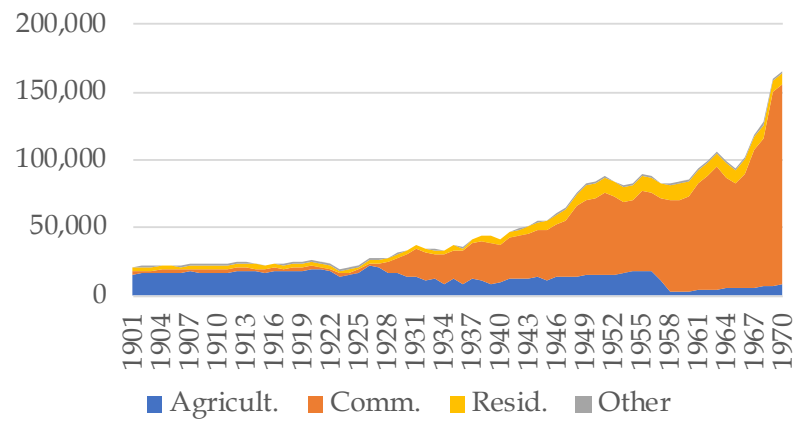

(C) King's: nominal gross income $(£)$

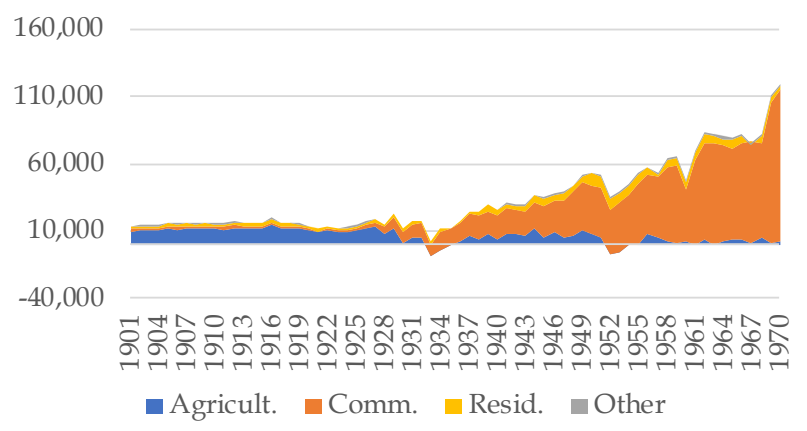

(E) King's: real gross income $(1970 £)$

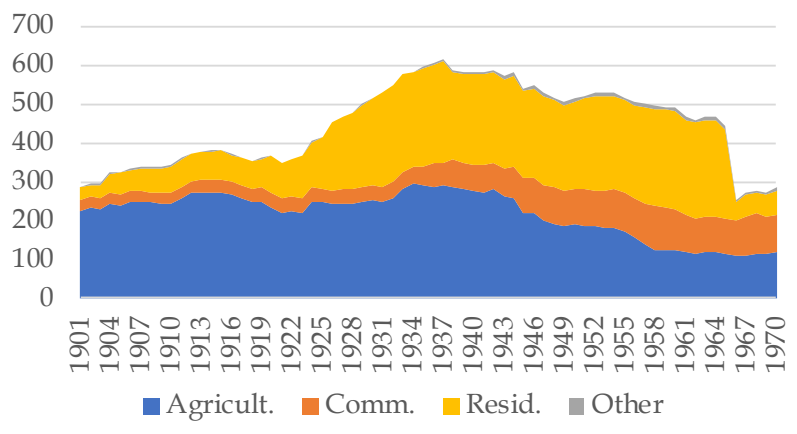

(B) Trinity: number of properties

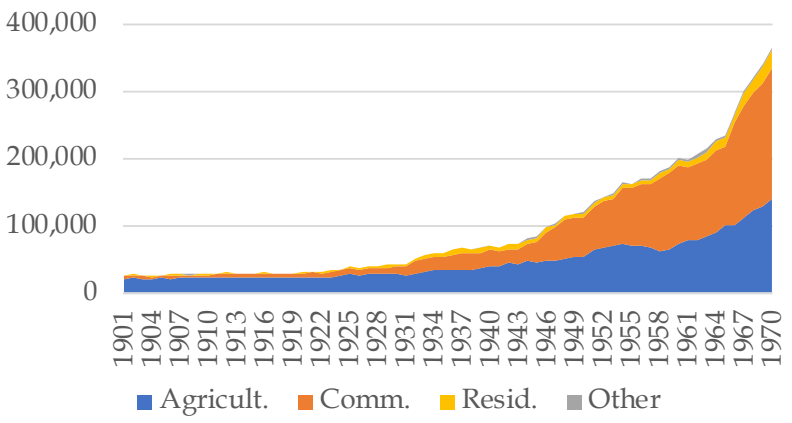

(D) Trinity: nominal gross income (£)

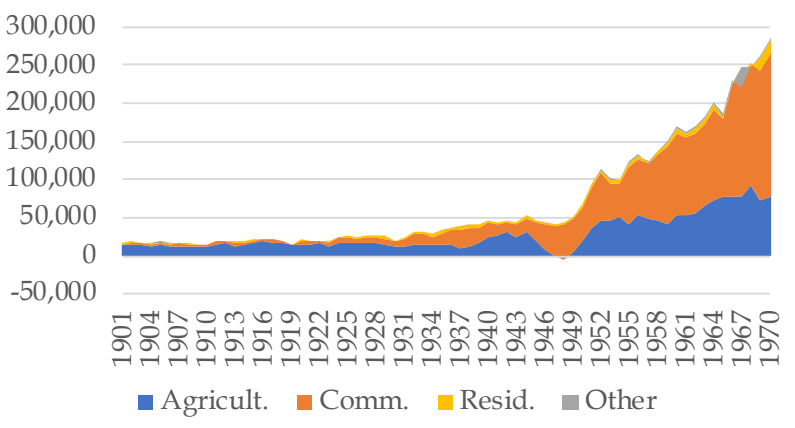

(F) Trinity: real gross income $(1970 £)$ 


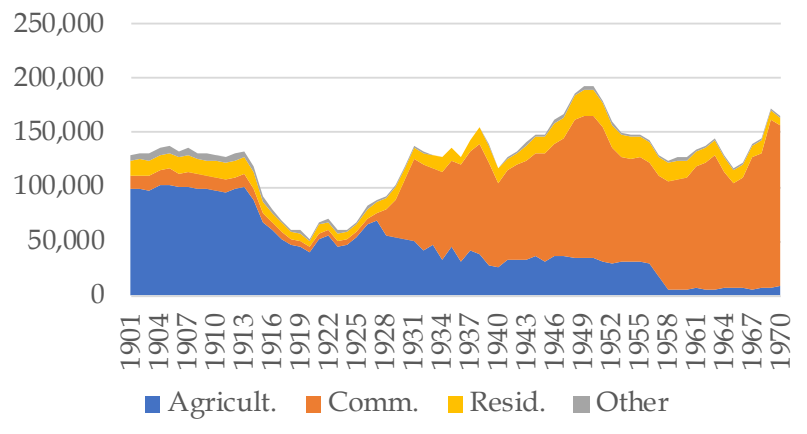

(G) King's: nominal net income (£)

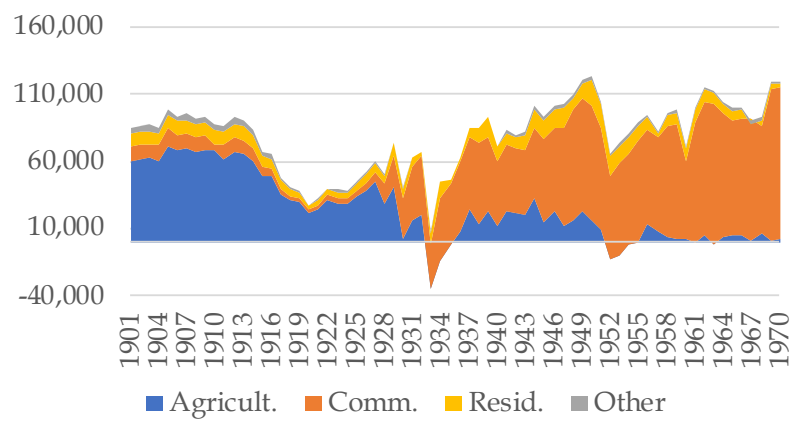

(I) King's: real net income $(1970 £)$

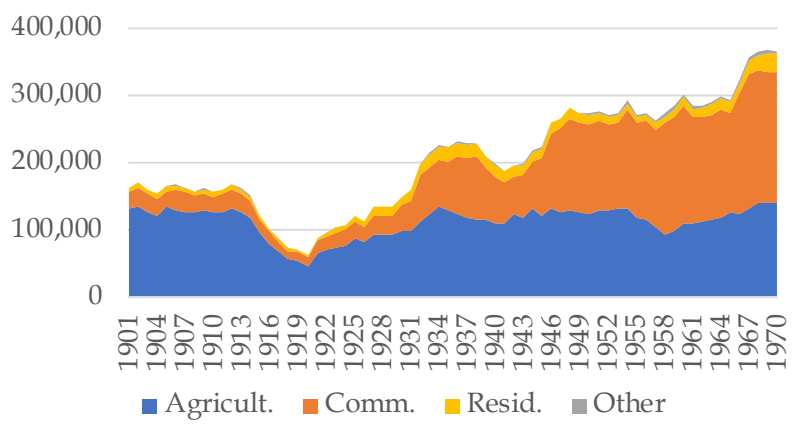

(H) Trinity: nominal net income (£)

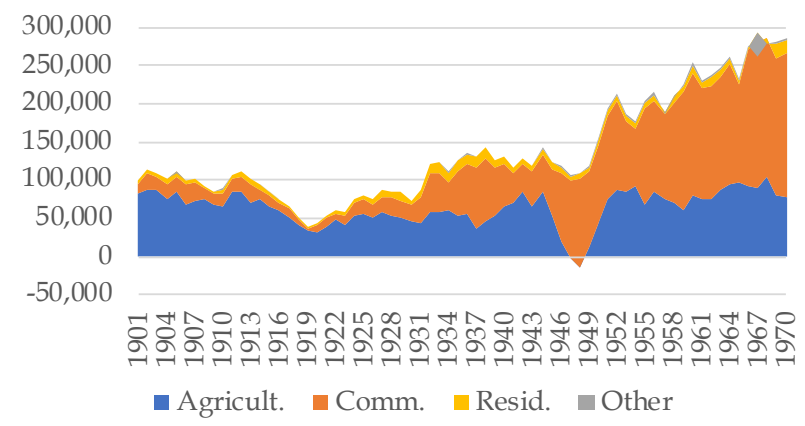

(J) Trinity: real net income $(1970 £)$ 
Figure 3. Income indices

This figure shows the estimated nominal income indices (in subfigure 3A) and real income indices (in subfigure 3B) over our sample period, for agricultural, commercial, and residential real estate separately and for all main property types together (excluding the "other" property type category). Subfigure 3B also shows annual inflation rates from Dimson et al. (2019) against the right axis.

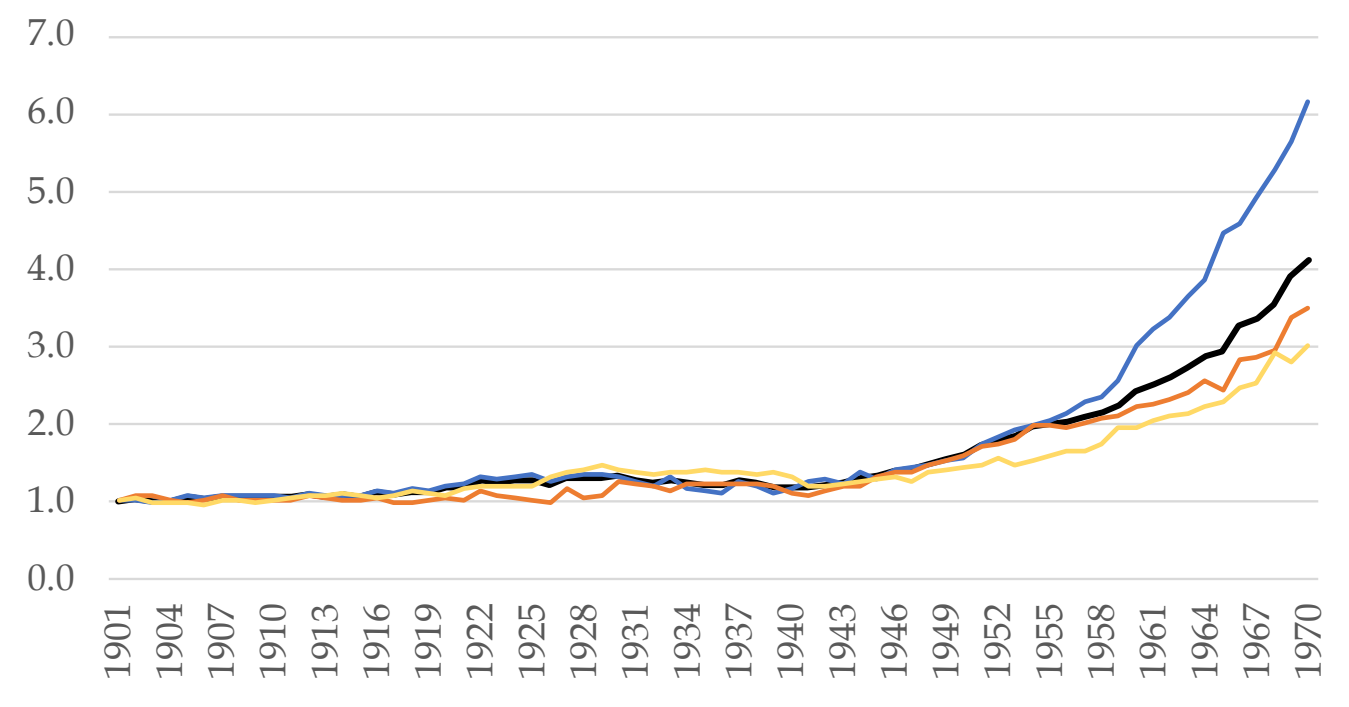

-ALL - Agricult. -Comm. - Resid.

(A) Nominal income indices

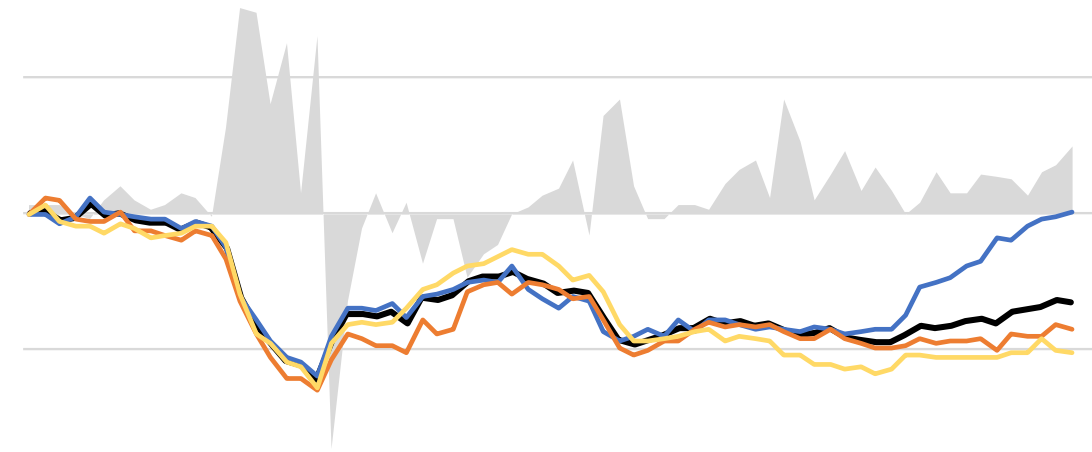

$20.0 \%$

\section{0}

0.5

0.0

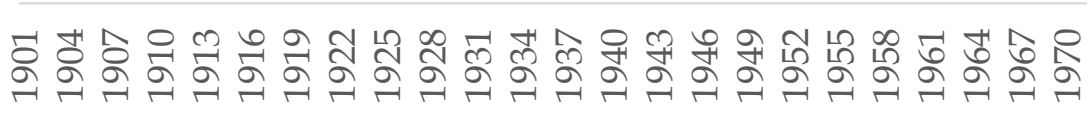

$10.0 \%$

$0.0 \%$

$-10.0 \%$

$-20.0 \%$

-ALL - Agricult. -Comm. - Resid. Inflation

$-30.0 \%$

(B) Real income indices 
Figure 4. Income yields

Subfigure $4 \mathrm{~A}$ shows the equal-weighted average, the value-weighted average, and the median of the estimated income yields measured over moving five-year intervals. Subfigure $4 \mathrm{~B}$ shows the equal-weighted average per property type measured over moving ten-year intervals.

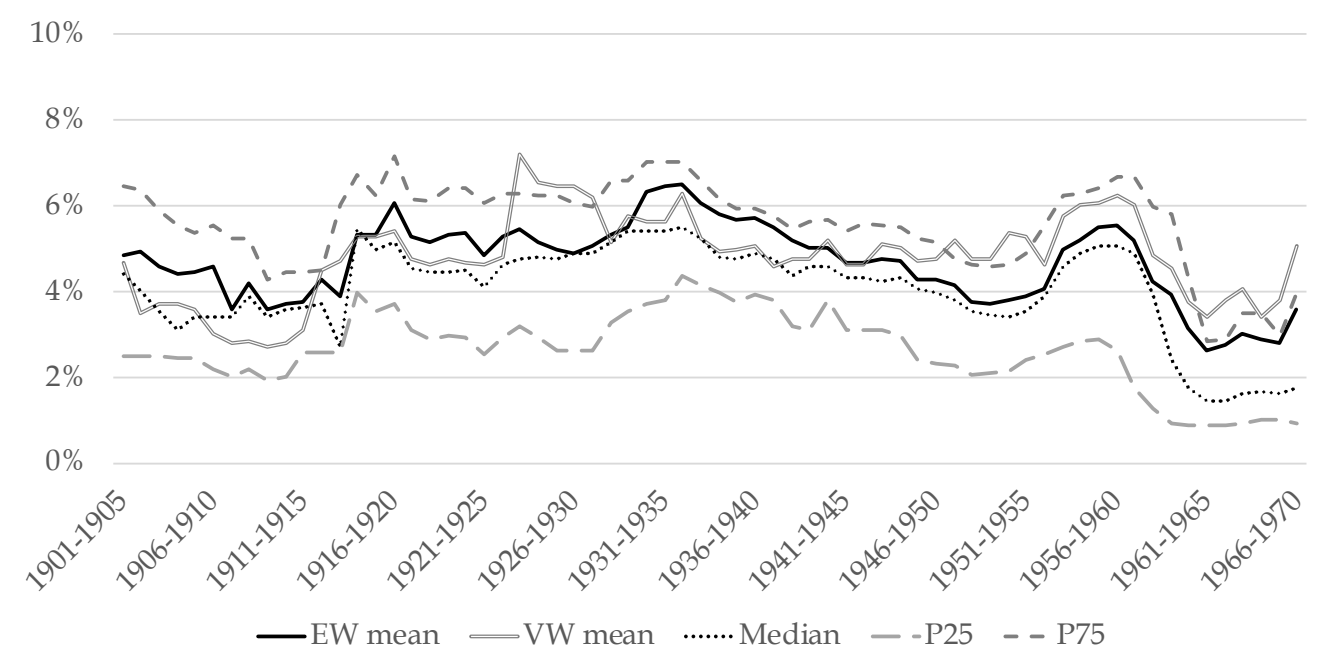

(A) All real estate

$10 \%$
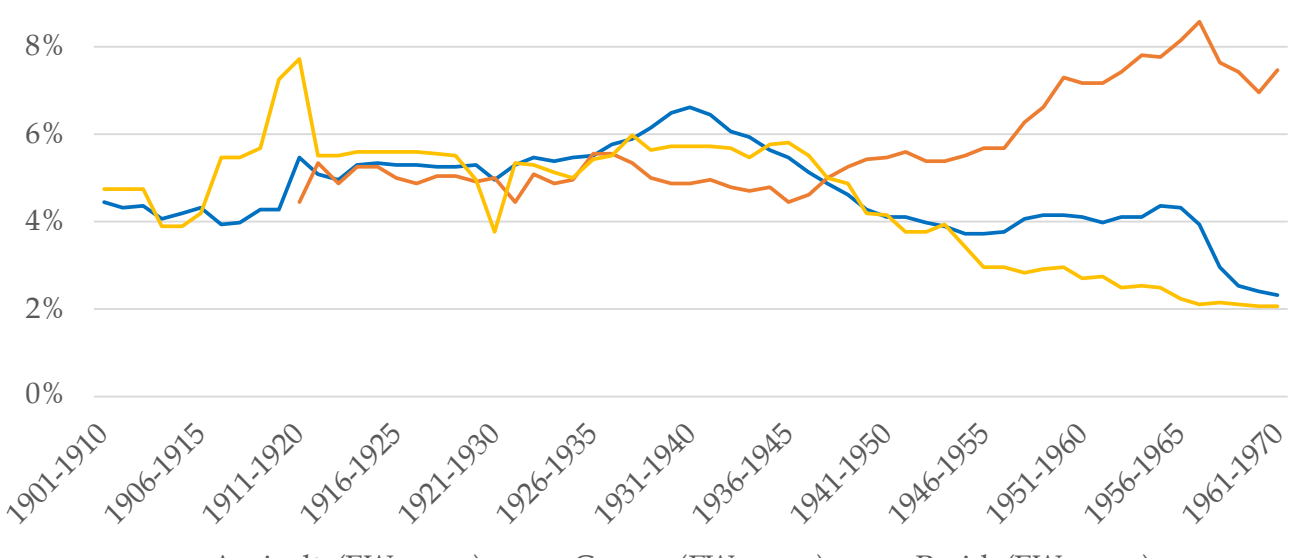

—Agricult. (EW mean) —Comm. (EW mean) —Resid. (EW mean)

(B) Per type 
Figure 5. The impact of costs

Subfigure 5A shows the yearly total cost-to-income ratio over our sample period, aggregated over the income observations for King's and Trinity College, for agricultural, commercial, and residential real estate separately and for all property types together. Subfigure 5B shows the yearly breakdown of costs for Trinity College.

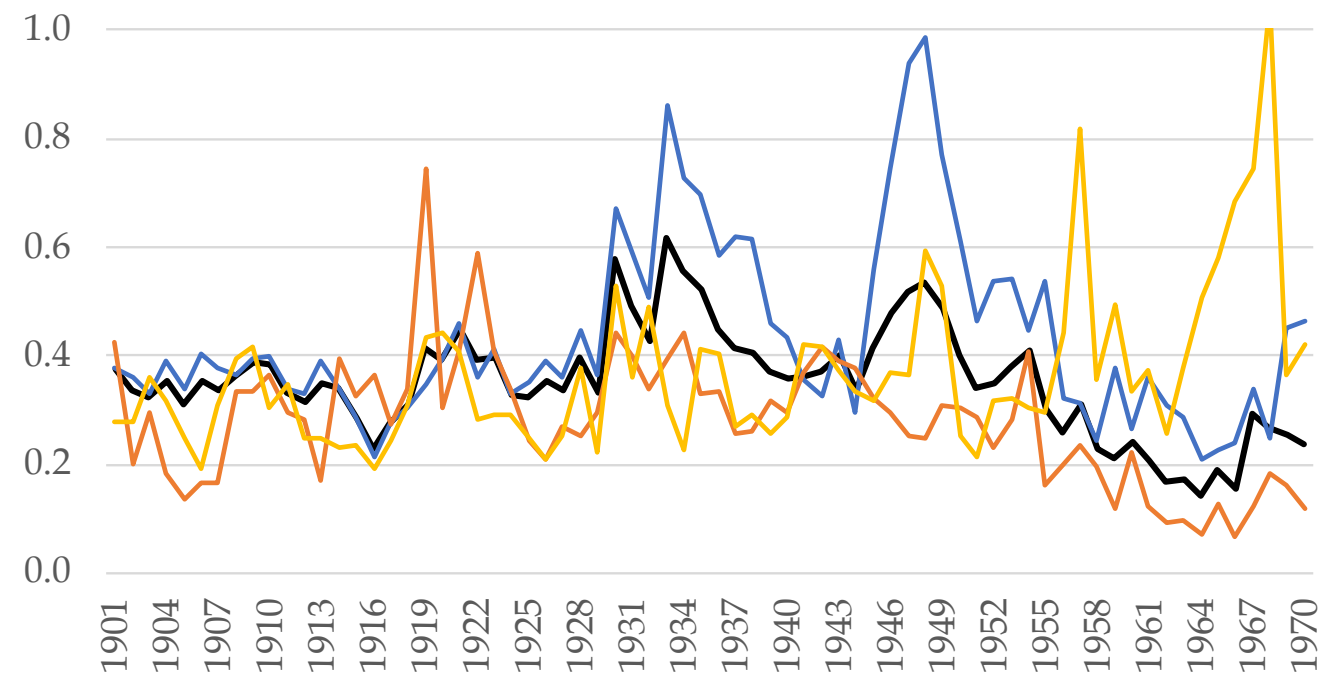

-ALL -Agricult. -Comm. - Resid.

(A) Annual cost-to-income ratios

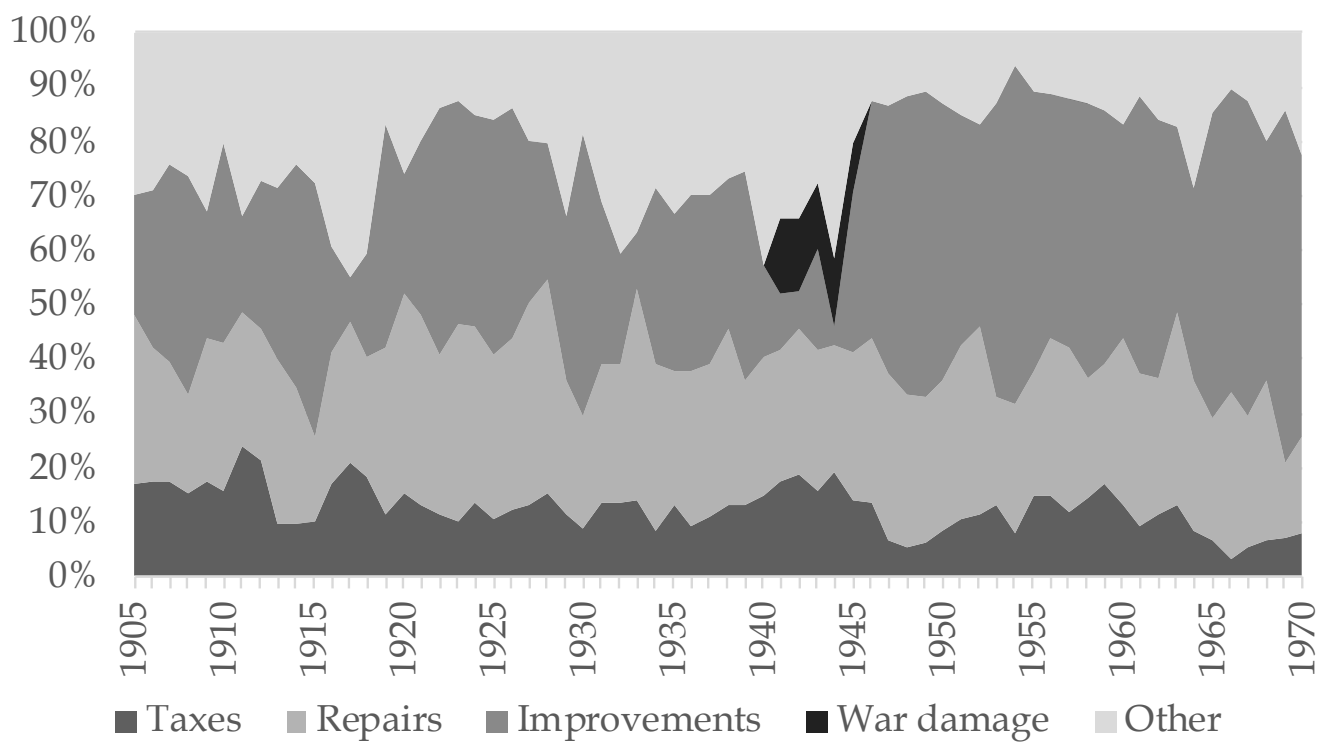

(B) Breakdown of costs 
Figure 6. Distribution of changes in income and net income

This figure shows the yearly distribution of property-level changes in gross income (in subfigure 6A) and net income (in subfigure 6B), using data from King's and Trinity College, over our sample period.

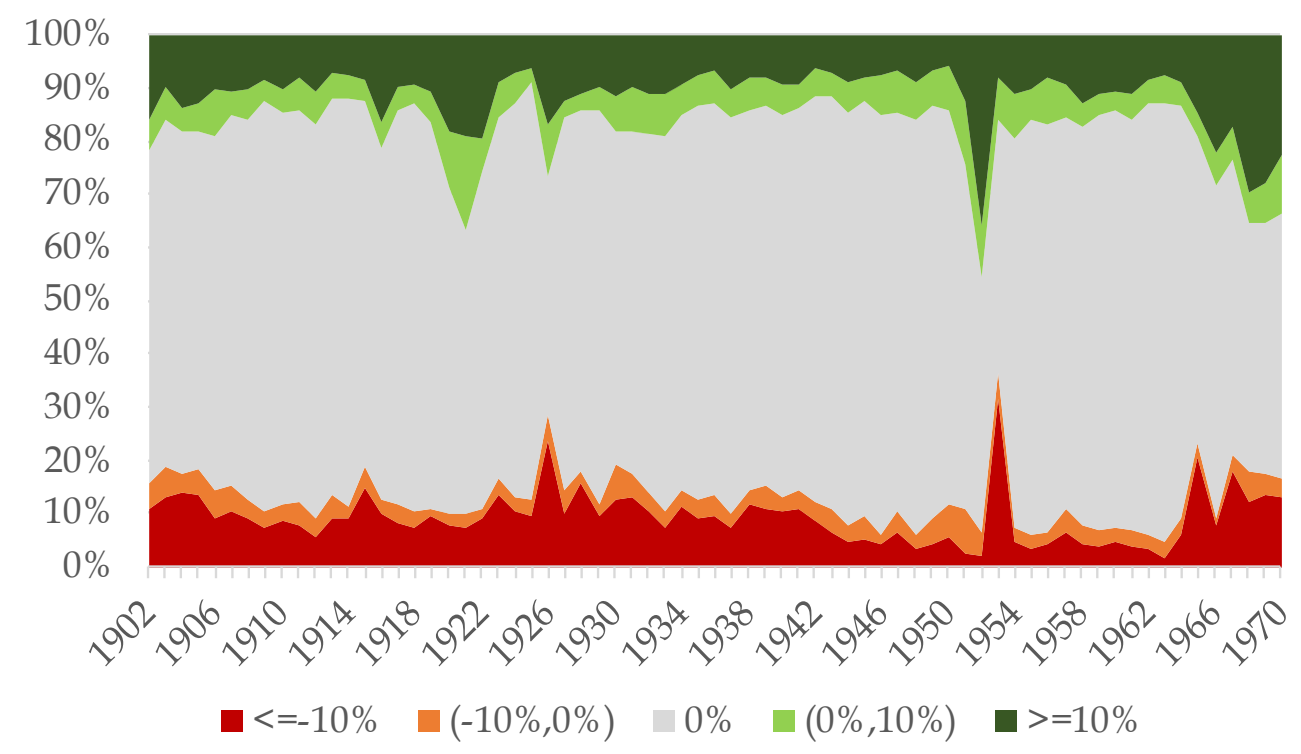

(A) Annual changes in income

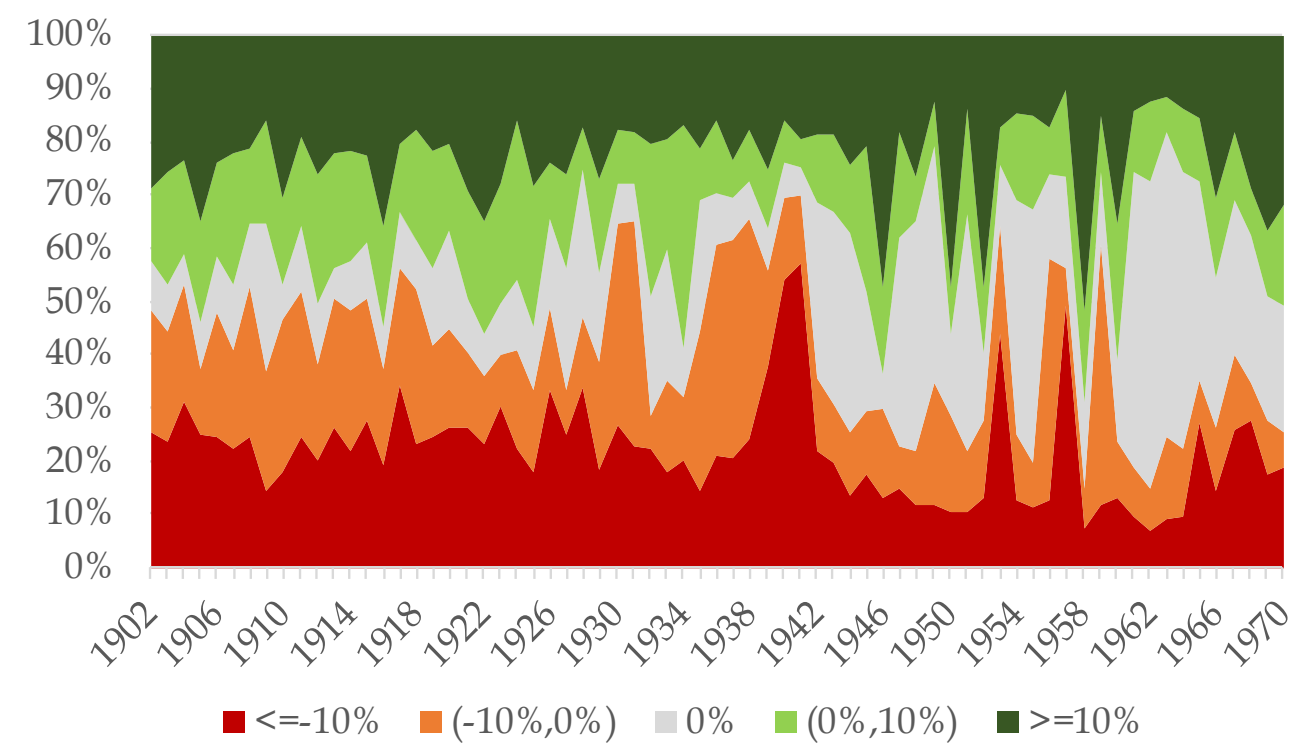

(B) Annual changes in net income 
Figure 7. Comparison of estimated housing rental income growth

This figure repeats our real income index for residential real estate from Subfigure 3B, and also shows the real housing rental income index for the U.K. used in Jordà et al. (2019a) and the quality-adjusted real housing rental income index for London estimated by Eichholtz et al. (2018).

10

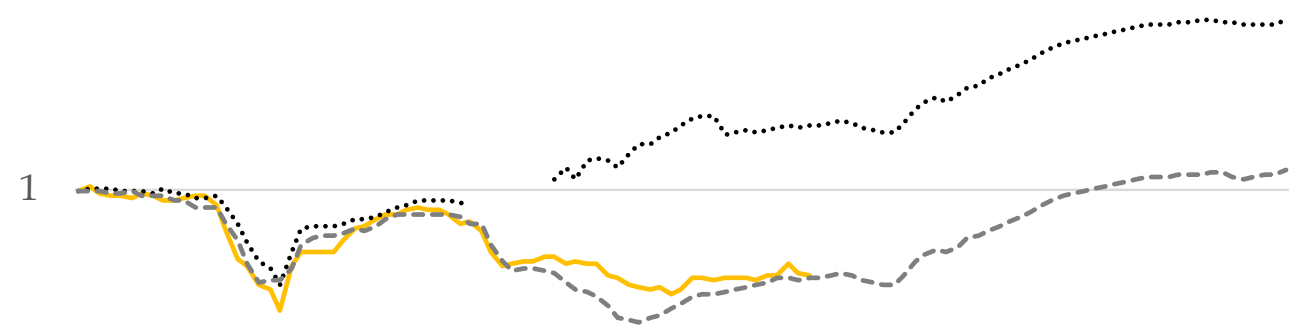

0

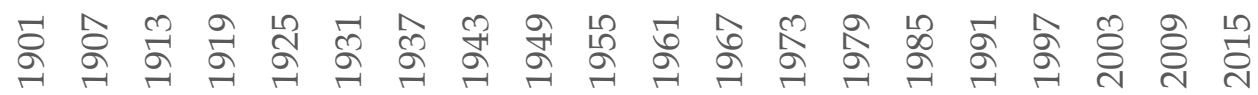

—Our estimates .......Jorda et al. (2019) ---.Eichholtz et al. (2018) 
Table 1. Composition of income data set

This table shows the number of property-year income observations and the number of distinct properties per decade (in Panel A), per college and property type (in Panel B), and per region (in Panel C).

Panel A. Distribution over decades

\begin{tabular}{lrr}
\hline & $N$ & $\#$ prop. \\
\hline $1901-1910$ & 6,666 & 828 \\
$1911-1920$ & 7,546 & 1,040 \\
$1921-1930$ & 7,074 & 1,305 \\
$1931-1940$ & 7,162 & 1,090 \\
$1941-1950$ & 7,814 & 1,118 \\
$1951-1960$ & 7,218 & 990 \\
$1961-1970$ & 5,133 & 785 \\
\hline Total & 48,613 & 2,949 \\
\hline
\end{tabular}

Panel B. Distribution over colleges and property types

\begin{tabular}{lrrrrrr}
\hline & Agricult. & Comm. & Resid. & Other & Total & \# prop. \\
\hline King's College & 7,100 & 2,257 & 5,354 & 1,040 & 15,751 & 915 \\
Trinity College & 15,191 & 4,315 & 11,426 & 337 & 31,269 & 1,541 \\
Christ Church & 989 & 147 & 68 & 19 & 1,223 & 356 \\
New College & 357 & 10 & 3 & 0 & 370 & 137 \\
\hline Total & 23,637 & 6,729 & 16,851 & 1,396 & 48,613 & 2,949 \\
\# prop. & 1,591 & 360 & 907 & 91 & 2,949 & \\
\hline
\end{tabular}

Panel C. Distribution over regions

\begin{tabular}{lrr}
\hline & $N$ & $\#$ prop. \\
\hline East Midlands & 8,064 & 403 \\
East of England & 21,616 & 1,025 \\
London & 5,207 & 340 \\
North East England & 61 & 3 \\
North West England & 730 & 41 \\
Scotland & 13 & 1 \\
South East England & 4,171 & 517 \\
South West England & 5,517 & 352 \\
Wales & 1 & 1 \\
West Midlands & 1,544 & 136 \\
Yorkshire and the Humber & 1,689 & 130 \\
\hline Total & 48,613 & 2,949 \\
\hline
\end{tabular}


Table 2. Composition of matched property-transactions data set

This table shows the number of matched income-transaction observations per decade and transaction type (in Panel A), per college and transaction type (in Panel B), per property type and transaction type (in Panel C), and per contract type and transaction type (in Panel D). In each panel, the last column shows the number of distinct transactions corresponding to each row.

Panel A. Distribution over decades and transaction types

\begin{tabular}{lrrrr}
\hline & Purchases & Sales & Total & $\#$ trans. \\
\hline $1901-1910$ & 26 & 48 & 74 & 67 \\
$1911-1920$ & 33 & 162 & 195 & 162 \\
$1921-1930$ & 42 & 311 & 353 & 324 \\
$1931-1940$ & 175 & 175 & 350 & 249 \\
$1941-1950$ & 193 & 250 & 443 & 265 \\
$1951-1960$ & 80 & 260 & 340 & 282 \\
$1961-1970$ & 36 & 181 & 217 & 193 \\
\hline Total & 585 & 1,387 & 1,972 & 1,542 \\
\hline
\end{tabular}

Panel B. Distribution over colleges and transaction types

\begin{tabular}{lrrrr}
\hline & Purchases & Sales & Total & \# trans. \\
\hline King's College & 193 & 431 & 624 & 463 \\
Trinity College & 242 & 484 & 726 & 578 \\
Christ Church & 95 & 347 & 442 & 341 \\
New College & 55 & 125 & 180 & 160 \\
\hline Total & 585 & 1,387 & 1,972 & 1,542 \\
\hline
\end{tabular}

Panel C. Distribution over property types and transaction types

\begin{tabular}{lrrrr}
\hline & Purchases & Sales & Total & \# trans. \\
\hline Agricultural & 234 & 955 & 1,189 & 994 \\
Commercial & 185 & 144 & 329 & 242 \\
Residential & 157 & 261 & 418 & 297 \\
Other & 9 & 27 & 36 & 35 \\
\hline Total & 585 & 1,387 & 1,972 & 1,542 \\
\hline
\end{tabular}

Panel D. Distribution over contract types and transaction types

\begin{tabular}{lrrrr}
\hline & Purchases & Sales & Total & \# trans. \\
\hline One complete property & 285 & 761 & 1,046 & 1,046 \\
Part of a property & 33 & 336 & 369 & 369 \\
Portfolio of properties & 267 & 290 & 557 & 127 \\
\hline Total & 585 & 1,387 & 1,972 & 1,542 \\
\hline
\end{tabular}


Table 3. Descriptive statistics income and prices

This table reports a number of descriptive statistics (number of observations, median, and mean) per decade for income and net income (in Panel A, where the unit of observation is a property-year combination), and for purchase and sale prices (in Panel B, where the unit of observation is a transaction).

Panel A. Gross income and net income

\begin{tabular}{|c|c|c|c|c|c|c|c|c|c|c|}
\hline \multirow[b]{3}{*}{ Decade } & \multicolumn{5}{|c|}{ Gross income } & \multicolumn{5}{|c|}{ Net income } \\
\hline & \multirow[b]{2}{*}{$N$} & \multicolumn{2}{|r|}{$£$} & \multicolumn{2}{|c|}{$1970 £$} & \multirow[b]{2}{*}{$N$} & \multicolumn{2}{|c|}{$£$} & \multicolumn{2}{|c|}{$1970 £$} \\
\hline & & Mean & Median & Mean & Median & & Mean & Median & Mean & Median \\
\hline 1901-1910 & 6,665 & 78 & 31 & 458 & 181 & 6,665 & 51 & 19 & 300 & 115 \\
\hline 1911-1920 & 7,546 & 76 & 30 & 289 & 101 & 7,528 & 52 & 18 & 198 & 63 \\
\hline $1921-1930$ & 7,062 & 97 & 26 & 304 & 82 & 7,045 & 61 & 15 & 189 & 46 \\
\hline $1931-1940$ & 7,142 & 141 & 26 & 494 & 91 & 7,132 & 78 & 12 & 270 & 44 \\
\hline $1941-1950$ & 7,797 & 211 & 30 & 539 & 79 & 7,792 & 122 & 16 & 311 & 40 \\
\hline 1951-1960 & 7,211 & 371 & 35 & 622 & 59 & 7,201 & 254 & 23 & 421 & 39 \\
\hline $1961-1970$ & 5,120 & 758 & 145 & 915 & 175 & 5,104 & 596 & 83 & 723 & 105 \\
\hline Total & 48,543 & 226 & 31 & 500 & 103 & 48,467 & 155 & 19 & 328 & 55 \\
\hline
\end{tabular}

Panel B. Purchase prices and sale prices

\begin{tabular}{|c|c|c|c|c|c|c|c|c|c|c|}
\hline \multirow[b]{3}{*}{ Decade } & \multicolumn{5}{|c|}{ Purchase prices } & \multicolumn{5}{|c|}{ Sale prices } \\
\hline & \multirow[b]{2}{*}{$N$} & \multicolumn{2}{|c|}{$£$} & \multicolumn{2}{|c|}{$1970 £$} & \multirow[b]{2}{*}{$N$} & \multicolumn{2}{|c|}{$£$} & \multicolumn{2}{|c|}{$1970 £$} \\
\hline & & Mean & Median & Mean & Median & & Mean & Median & Mean & Median \\
\hline $1901-1910$ & 25 & 2,980 & 800 & 17,794 & 4,553 & 42 & 2,061 & 630 & 12,044 & 3,784 \\
\hline 1911-1920 & 17 & 5,123 & 2,525 & 17,653 & 9,470 & 145 & 1,566 & 600 & 4,573 & 1,886 \\
\hline 1921-1930 & 42 & 4,893 & 1,000 & 15,302 & 3,289 & 282 & 2,344 & 1,192 & 7,217 & 3,529 \\
\hline 1931-1940 & 104 & 10,382 & 6,820 & 35,831 & 22,386 & 145 & 3,355 & 475 & 11,862 & 1,711 \\
\hline 1941-1950 & 77 & 22,645 & 18,500 & 57,905 & 43,429 & 188 & 4,152 & 1,119 & 10,465 & 2,681 \\
\hline 1951-1960 & 65 & 15,272 & 9,000 & 25,711 & 15,811 & 217 & 10,924 & 3,360 & 18,246 & 6,076 \\
\hline 1961-1970 & 30 & 20,304 & 15,500 & 24,296 & 19,374 & 163 & 12,654 & 1,500 & 15,417 & 1,959 \\
\hline Total & 360 & 13,312 & 6,688 & 33,258 & 17,408 & 1,182 & 5,647 & 1,200 & 11,306 & 2,696 \\
\hline
\end{tabular}




\section{Table 4. Drivers of variation in income}

This table shows the results of OLS regressions with the estimated annual percentage changes in nominal income (in column 1) or real income (in column 2) as the dependent variable. These annual growth rates are computed from the indices shown in Figure 3. The independent variables are GDP growth rates taken from Johnston and Williamson (2019), and (lagged) equity returns and inflation rates taken from Dimson et al. (2019). GDP growth rates and equity returns are measured in nominal terms in column 1 and in real terms in column 2.

\begin{tabular}{lrr}
\hline & $(1)$ & $(2)$ \\
& Nominal & Real \\
\hline GDP growth rate & 0.108 & 0.005 \\
& $(0.099)$ & $(0.138)$ \\
Lagged equity return & $0.069 * *$ & 0.031 \\
& $(0.027)$ & $(0.027)$ \\
Inflation rate & -0.064 & $-0.969 * * *$ \\
& $(0.097)$ & $(0.069)$ \\
\hline$N$ & 69 & 69 \\
$R^{2}$ & 0.119 & 0.764 \\
\hline
\end{tabular}


Table 5. Income growth rates

This table shows annualized income growth rates, in nominal terms (Panel A) and real terms (Panel B), over our complete sample period and three different subperiods.

Panel A. Annualized nominal gross income growth rates

\begin{tabular}{lrrrr}
\hline & All & Agricultural & Commercial & Residential \\
\hline Pre-WWI (1901-1913) & $0.6 \%$ & $0.6 \%$ & $0.3 \%$ & $0.7 \%$ \\
1914-1945 & $0.7 \%$ & $0.6 \%$ & $0.7 \%$ & $0.6 \%$ \\
Post-WWII (1946-1970) & $4.6 \%$ & $6.4 \%$ & $4.0 \%$ & $3.4 \%$ \\
\hline $1901-1970$ & $2.1 \%$ & $2.7 \%$ & $1.8 \%$ & $1.6 \%$ \\
\hline
\end{tabular}

Panel B. Annualized real gross income growth rates

\begin{tabular}{lrrrr}
\hline & All & Agricultural & Commercial & Residential \\
\hline Pre-WWI (1901-1913) & $-0.4 \%$ & $-0.4 \%$ & $-0.7 \%$ & $-0.4 \%$ \\
$1914-1945$ & $-1.5 \%$ & $-1.6 \%$ & $-1.4 \%$ & $-1.6 \%$ \\
Post-WWII (1946-1970) & $0.6 \%$ & $2.3 \%$ & $0.0 \%$ & $-0.6 \%$ \\
\hline $1901-1970$ & $-0.6 \%$ & $0.0 \%$ & $-0.8 \%$ & $-1.0 \%$ \\
\hline
\end{tabular}


Table 6. Income yields

This table shows a number of descriptive statistics for the estimated yields per subperiod (in Panel A) and per property type and subperiod (in Panels B-D). We omit estimates for commercial real estate for the pre-WWI period for which we have less than five observations.

Panel A. All real estate

\begin{tabular}{lrrrrrr}
\hline & N & EW mean & VW mean & Median & P25 & P75 \\
\hline Pre-WWI (1901-1913) & 48 & $4.4 \%$ & $3.4 \%$ & $3.6 \%$ & $2.3 \%$ & $5.6 \%$ \\
1914-1945 & 499 & $5.4 \%$ & $5.2 \%$ & $4.7 \%$ & $3.3 \%$ & $6.2 \%$ \\
Post-WWII (1946-1970) & 495 & $4.1 \%$ & $5.0 \%$ & $3.5 \%$ & $1.7 \%$ & $5.3 \%$ \\
\hline
\end{tabular}

Panel B. Agricultural real estate

\begin{tabular}{lrrrrrr}
\hline & N & EW mean & VW mean & Median & P25 & P75 \\
\hline Pre-WWI (1901-1913) & 39 & $4.3 \%$ & $3.2 \%$ & $3.6 \%$ & $2.0 \%$ & $5.4 \%$ \\
1914-1945 & 338 & $5.4 \%$ & $5.0 \%$ & $4.8 \%$ & $3.3 \%$ & $6.2 \%$ \\
Post-WWII (1946-1970) & 229 & $3.8 \%$ & $4.0 \%$ & $3.6 \%$ & $2.2 \%$ & $4.8 \%$ \\
\hline
\end{tabular}

Panel C. Commercial real estate

\begin{tabular}{lrrrrrr}
\hline & $\mathrm{N}$ & EW mean & VW mean & Median & P25 & P75 \\
\hline 1914-1945 & 87 & $4.9 \%$ & $5.6 \%$ & $4.5 \%$ & $3.2 \%$ & $5.7 \%$ \\
Post-WWII (1946-1970) & 115 & $6.8 \%$ & $6.1 \%$ & $5.9 \%$ & $4.3 \%$ & $8.3 \%$ \\
\hline
\end{tabular}

Panel D. Residential real estate

\begin{tabular}{lrrrrrr}
\hline & N & EW mean & VW mean & Median & P25 & P75 \\
\hline Pre-WWI (1901-1913) & 6 & $4.8 \%$ & $2.8 \%$ & $4.3 \%$ & $2.9 \%$ & $7.4 \%$ \\
1914-1945 & 74 & $5.7 \%$ & $5.2 \%$ & $4.8 \%$ & $3.8 \%$ & $6.5 \%$ \\
Post-WWII (1946-1970) & 151 & $2.4 \%$ & $2.9 \%$ & $1.7 \%$ & $1.1 \%$ & $3.1 \%$ \\
\hline
\end{tabular}


Table 7. Drivers of variation in yields

This table shows the results of an OLS regression with the estimated transaction-level yields as the dependent variable. The independent variables are a number of fixed effect sets and dummies indicating whether the transaction is a purchase (instead of a sale), is a portfolio transaction or not, relates to commercial or residential (instead of agricultural) real estate, and is associated with a change of use (e.g., agricultural land being sold with a permission for residential development).

\begin{tabular}{lr}
\hline & Yield \\
\hline Purchase & $0.009 * * *$ \\
& $(0.003)$ \\
Portfolio transaction & 0.001 \\
& $(0.004)$ \\
Commercial & $0.012^{* * *}$ \\
& $(0.003)$ \\
Residential & $-0.006 *$ \\
& $(0.004)$ \\
Change of use & -0.004 \\
& $(0.004)$ \\
College fixed effects & Yes \\
Property region fixed effects & Yes \\
Transaction year fixed effects & Yes \\
\hline$N$ & 1,042 \\
$R^{2}$ & 0.200 \\
\hline
\end{tabular}


Table 8. Approximation of real annualized net total returns

This table shows our estimation of the annualized net total returns over our time frame, in real terms, for the different real estate types.

\begin{tabular}{lrrrrrrr}
\hline & \multicolumn{3}{c}{$\begin{array}{c}\text { Avg. } \\
\text { net yield }\end{array}$} & \begin{tabular}{l}
$1+g_{\eta, 1901 \rightarrow 1970}$ \\
\cline { 2 - 6 }
\end{tabular} & $\begin{array}{c}\overline{y_{\eta, 1901}^{*}} \\
y_{\eta, 1970}^{*}\end{array}$ & $\begin{array}{c}\text { Avg. } \\
\text { cap. gain }\end{array}$ & $\begin{array}{r}\text { Avg. } \\
\text { total return }\end{array}$ \\
\hline Agricultural & $4.7 \%$ & $43.4 \%$ & $2.7 \%$ & 1.00 & 1.92 & $1.1 \%$ & $3.8 \%$ \\
Commercial & $5.7 \%$ & $28.2 \%$ & $4.1 \%$ & 0.57 & 0.60 & $-1.8 \%$ & $2.3 \%$ \\
Residential & $4.5 \%$ & $36.7 \%$ & $2.8 \%$ & 0.49 & 2.30 & $0.2 \%$ & $3.0 \%$ \\
\hline
\end{tabular}




\section{Appendix A Archival Sources}

Table A.1. Archival sources used in construction of database

This table reports details on the archival data sources used in the construction of our property database. For King's College, the relevant citation information is: Mundum Part I: KCAR/4/1/1/1901/1 to KCAR/4/1/1/1970/1; Ledger Books: KCAR/3/3/1/1/22 to KCAR/3/3/1/1/36; Estates Committee Minutes Book: KCGB/6/18/1/2 to KCGB/6/18/1/11. For Trinity College: Rent Books 1901-1960; Rent Book-Lands: 1960-1971; Rent Book-Houses: 1960-1971; Sealed Books: 1900-1970. For Christ Church: Rack Rental Ledgers 1900-1911 (handwritten): xxviii.b.1-16; Rack Rental Ledgers 1912-1968 (handwritten): xxviii.c.1-38; Estate Books (Printed Rent Books) xxi.b.1-37; Estate Ledgers Books xx.c.45-64. For New College: Rack Rent books (handwritten) 1903-1929: NCA EST/B6, NCA EST/B7, NCA EST/B8; Register of Estates \& other properties (Printed Rent Books): NCA 8597-8602: 1927, 1930, 1935, 1939, 1947, 1953. 6 vols; Registers of leases and conveyances: NCA REG/D38- D41: 1904-1925, 1925-1935, 1936-1955, 1955-1973; Registers of land purchases: NCA REG/E7 and NCA REG/E8: 1870-1936 and 1937-1972.

\begin{tabular}{|c|c|}
\hline Data item & Source \\
\hline \multicolumn{2}{|c|}{ Panel A: King's College, Cambridge } \\
\hline Income and cost, actual & Mundum Part I 1901-1970 \\
\hline Transaction value & Ledger Books 1901-1970 \\
\hline Transaction characteristics & Ledger Books 1901-1970 \\
\hline Property characteristics & Estates Committee Minutes Books, Ledger Books, Mundum Part I, all 1901-1970 \\
\hline \multicolumn{2}{|c|}{ Panel B: Trinity College, Cambridge } \\
\hline Income and cost, actual & $\begin{array}{l}\text { Rent Books 1901-1960; Rent Book-Lands 1960-1971; Rent Book-Houses 1960- } \\
1971\end{array}$ \\
\hline Transaction value & Sealed Books 1901-1970 \\
\hline Transaction characteristics & Sealed Books 1901-1970 \\
\hline Property characteristics & Sealed Books \& Rent Books \\
\hline \multicolumn{2}{|l|}{ Panel C: Christ Church, Oxford } \\
\hline Income and cost, actual & Rack Rental Ledgers \& College Ground Rent Books 1901-1968 \\
\hline Income and cost, contractual & $\begin{array}{l}\text { Estate Books 1911-1931, 1933, 1934, 1937,1938, 1940, 1942, 1947, 1951, 1956, 1964, } \\
1967,1970\end{array}$ \\
\hline Transaction value & Estate Ledgers Books \& Estate Books 1901-1970 \\
\hline Transaction characteristics & Estate Ledgers Books \\
\hline Property characteristics & Estate Ledgers Books \& Estate Books \\
\hline \multicolumn{2}{|l|}{ Panel D: New College, Oxford } \\
\hline Income and cost, actual & Rack Rent Books 1903-1929 \\
\hline Income and cost, contractual & $\begin{array}{l}\text { Register of Estates \& Other Properties 1904, 1912, 1922, 1927, 1930, 1935, 1939, } \\
1947,1953\end{array}$ \\
\hline Transaction value & $\begin{array}{l}\text { Registers of Leases \& Conveyances; Registers of Land Purchases; and Register of } \\
\text { Estates \& Other Properties }\end{array}$ \\
\hline Transaction characteristics & Registers of Leases \& Conveyances; Registers of Land Purchases \\
\hline Property characteristics & $\begin{array}{l}\text { Registers of Leases \& Conveyances; Registers of Land Purchases; Register of Es- } \\
\text { tates \& Other Properties }\end{array}$ \\
\hline
\end{tabular}




\section{Appendix B Treatment of 1925 and 1926 Income Data}

For King's, we impute the year-1926 income as the average of the year-1925 and the year1927 income for cases where the income in 1926 is between $50 \%$ and $100 \%$ of that in those surrounding years. For Trinity, we put the year-1926 income equal to the year-1927 income if the recorded value in 1926 is between $50 \%$ and $100 \%$ of the income in 1927, while we equate the year-1925 income to the year-1924 income if the recorded value in 1925 is higher than that in the surrounding years. We make property-level changes to the costs proportional to the changes in income. 